\title{
PHEBUS On-line Aerosol Moritor Development Test Program
}
M. H. Sprenger
C. G. Pentecost

Published March 1992

Idaho National Engineering Laboratory

EG\&G Idaho, Inc. Idaho Falls, Idaho 83415

Prepared for the Division of Accident Evaluation Office of Nuclear Regulatory Research U.S. Nuclear Regulatory Commission Washington, D.C. 20555 Under DOE Idaho Field Office Contract DE.-AC07-761D01570 FIN L1839 


\section{ABSTRACT}

EG\&G Idaho, Inc. developed an on-line aerosol monitor (OLAM) for the French PHEBUS Fission Product Project. Part of the development was to manufaciure and test an OLAM prototype. This report presents the results of the testing, which determined the mechanical integrity of the monitor at operating temperature and pressure and performed a preliminary test of the optical system. A series of twenty different tests was conducted during the prototype testing sequence. Since no leaks were detected, the OLAM demonstrated that it could provide a pressure boundary at required test conditions. The optical and electrical system also proved its integrity by exceeding the design requirement of less than $10 \%$ optical signal drift during an actual two-hour test sequence. 


\section{CONTENTS}

ABSTRACT $\ldots \ldots \ldots \ldots \ldots \ldots \ldots \ldots \ldots \ldots \ldots \ldots \ldots \ldots \ldots \ldots \ldots \ldots \ldots$

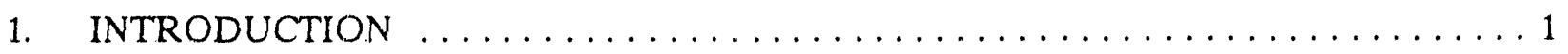

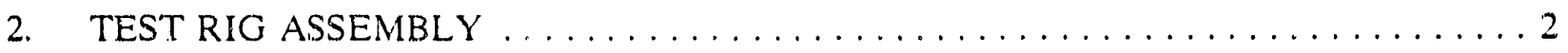

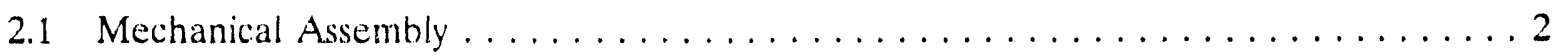

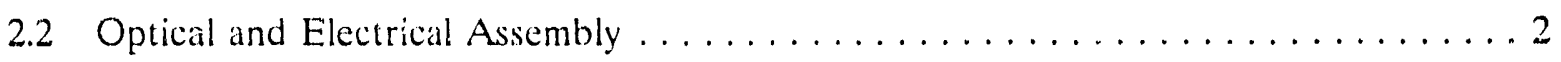

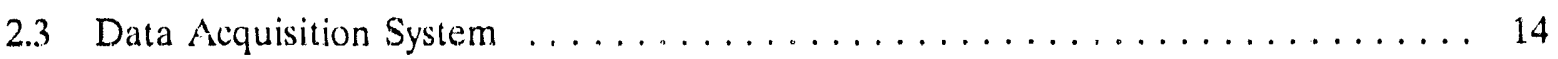

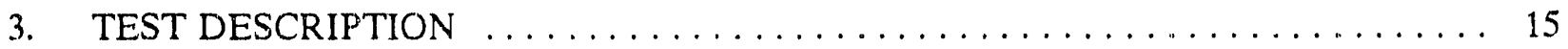

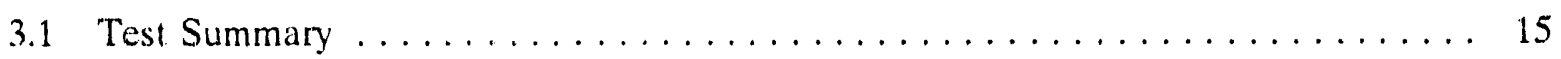

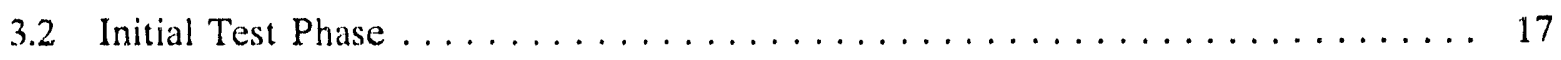

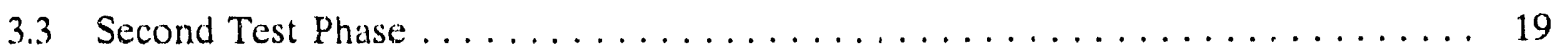

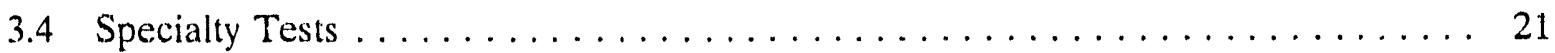

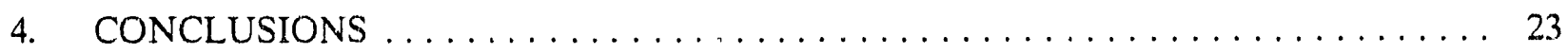

APPENDIX A-TEST PLAN FOR OLAM TESTING $\ldots \ldots \ldots \ldots \ldots \ldots \ldots \ldots \ldots$

\section{FIGURES}

1. PHEBUS aerosol monitor test $n$ g assembly $\ldots \ldots \ldots \ldots \ldots \ldots \ldots \ldots \ldots \ldots$

2. Detail of the PHEBUS aerosol monitor test rig assembly $\ldots \ldots \ldots \ldots \ldots \ldots \ldots$

3. Photograph of the on-line aerosol monitor $\ldots \ldots \ldots \ldots \ldots \ldots \ldots \ldots \ldots \ldots$

4. Piping and instrument diagram of the PHEBUS aerosol monitor test rig $\ldots \ldots \ldots \ldots$

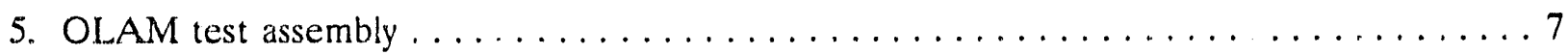

6. PHEBUS aerosol monitor diamond window assembly $\ldots \ldots \ldots \ldots \ldots \ldots \ldots \ldots$

7. Diamond window purge assembly $\ldots \ldots \ldots \ldots \ldots \ldots \ldots \ldots \ldots \ldots \ldots$ 


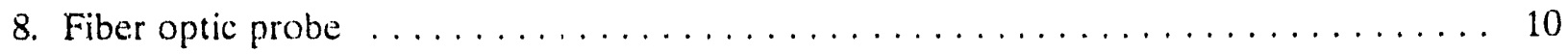

9. PHEBUS aerosol monitor tïber alignment assembly $\ldots \ldots \ldots \ldots \ldots \ldots \ldots \ldots \ldots$

10. Optical signal and detection electronics in the OLAM system $\ldots \ldots \ldots \ldots \ldots \ldots \ldots$

11. OLAM optical and electrical system $\ldots \ldots \ldots \ldots \ldots \ldots \ldots \ldots \ldots \ldots \ldots \ldots$

12. Representative temperature ramp used in NHLF test sequence $\ldots \ldots \ldots \ldots \ldots \ldots \ldots$

13. Characteristic signal decrease tound during initial test phase $\ldots \ldots \ldots \ldots \ldots \ldots \ldots$

14. Stable optical signal demonstrated after system modilications $\ldots \ldots \ldots \ldots \ldots \ldots$

15. Mechanical integrity of the OLAM at high pressures and temperatures $\ldots \ldots \ldots 22$

\section{TABLES}

1. Comprehensive list of tests pertormed with OLAM $\ldots \ldots \ldots \ldots \ldots \ldots \ldots$

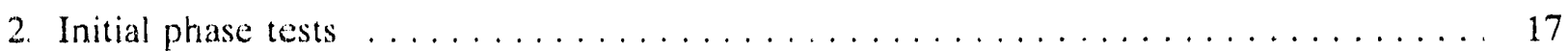

3. Second phase tests incorporating system modifications $\ldots \ldots \ldots \ldots \ldots \ldots \ldots \ldots$

4. Special purpose tests performed during the initial and second phases $\ldots \ldots \ldots \ldots 21$ 


\section{PHEBUS On-line Aerosol Monitor Development Test Program}

\section{INTRODUCTION}

EG\&G Idaho, Inc. is developing an on-line aerosol monitor (OLAM) for the French PHEBUS Fission Product Project (PHEBUS-FP). The monitor is being provided as in-kind support from the U.S. Nuclear Regulatory Commission (NRC), who is also funding the EG\&G Idaho efforts.

The PHEBUS.FP project (located in Cadarache, France) simulates the reactor core, primary circuit, and containment building of a full-size pressurized water reactor to allow the study of severe accident conditions in a controlled manner. A driver core is used to control a one-meter long test bundle containing approximately 20 tuel rods. The fission product release is expected to be about one five-thousandth of that of a full-size core. The primary coolant flow is directed from the test bundle up through a heated section of line into a horizontal line to a steam generator, cold leg, and containment tank; all this equipment will be placed in a containment structure (caisson). The aerosol monitor will be located in the horizontal line that runs from the heated section to the stearn generator within the caisson. The OLAM will be used to measure aerosols generated during the tests.

The OLAM designed for the PHEBUS-FP project is based on a successful instrument previously developed for use in the U.S. Department of Energy's Power Burst Facility. The monitor detects aerosols generated during testing by passing a light beam through the gas flow stream and measuring the change in light intensity caused by the presence of particles. The change in light intensity is a function of the particle concentration, particle size, and path length. By using fiber optics, the light is transmitted through the viewing ports across the flow stream to the receiving ports. The major components of the monitor are a light source, light detector, signal electronics and optics, and the mechanical parts required to implement the task.

In supporting the PHEBUS-FP project, EG\&G Idaho is responsible for designing the mechanical and optical systems of the OLAM, manufacturing and testing an OLAM prototype, and manufacturing and assembling the final deliverable monitor. To verify the mechanical and

- optical design, a test plan was formulated (see Appendix A). The testing was performed at the North Holmes Lab Facility (NHLF) at the Idaho National Engineering Laboratory (INEL) on a prototype monitor. The objectives of the tests were to ensure the mechanical integrity of the monitor at operating temperature and pressure, and to perform a preliminary test on the design of the optical system. This report documents the test results recorded during the NHLF testing process. 


\section{TEST RIG ASSEMBLY}

\subsection{Mechanical Assembly}

The mechanical setup of the OLAM itself is shown in Figures 1,2, and 3, and the test assembly is shown in Figures 4 and 5. The OLAM consists of a straight pipe spool section, called the sample block, through which the fluid and aerosols flow (Item \#4 in Figure 1). Two identical light ports are connected to the main spool section at right angles. The light ports are made up of two connecting components. The first component is called the housing (Item \#8 in Figure 1). The housing, sample block, and the diamond window assembly make up the primary chamber, which acts as the first containment boundary against release of the flow constituents. Figure 6 shows the diamond window assembly. The diamond window assembly houses and protects the fiber optic probes from the tluid tlow and high pressures in the sample block. The primary chamber also contains the diamond window purge system, which uses a nitrogen flow to keep the window's clean during operation (see Figure 7).

The second component is called the cover assembly. The cover assembly and the attached fiber optic probe make up the secondary chamber, which functions as the secondary containment if the diamond window fails during operation. The fiber optic probe is shown in Figure 8. The probe is potted into a $1.6-\mathrm{mm}(1 / 16-\mathrm{in}$.) tube using a high-temperature ceramic adhesive, and then polished to ensure a clean optic signal (see Figure 9). The final deliverable OLAM will have the same design except a dual light port system will be used to detect the flow path aerosols.

The remaining parts in the test rig assembly include the following: a nitrogen and hydrogen supply used to pressurize the OLAM; two tubular, 1120-W wrap heaters and a ceramic fiber insulation jacket that enable the OLAM to be ramped to $704^{\circ} \mathrm{C}\left(1300^{\circ} \mathrm{F}\right)$; a vacuum pump, system of valves, flow meters, pressure transducers and gauges, thermocouples, and lengths of tubing.

\subsection{Optical and Electrical Assembly}

The optical and electrical system is shown in Figures 10 and 11. The light source is generated by a light emitting diode (LED), which is driven by a dc current source and modulated by a sine wave. The sine wave also acts as the reference input to two lock-in amplifiers. The output of the LEF is coupled to a beamsplitter. The beamsplitter sends a small portion of the signal directly to a silicon detector/amplifier that serves as a comparative source. The remainder of the signal is transmitted to the diam snd window through a gold-jacketed, fused-silira fiber (see Figure 8). The signal traverses the main spool flow stream, is collected in the receiving port by another length of fiber optic cable, and is then carried to an identical detector/amplifier. The detected output signals serve as inputs to the lock-in amplifiers. The lock-in amplifiers filter noise out of the optic signals by using phase comparison and provide the final amplification. In the test sequence, the optical signal, through the spool piece, was observed for sufficient transmission strength and stability. 


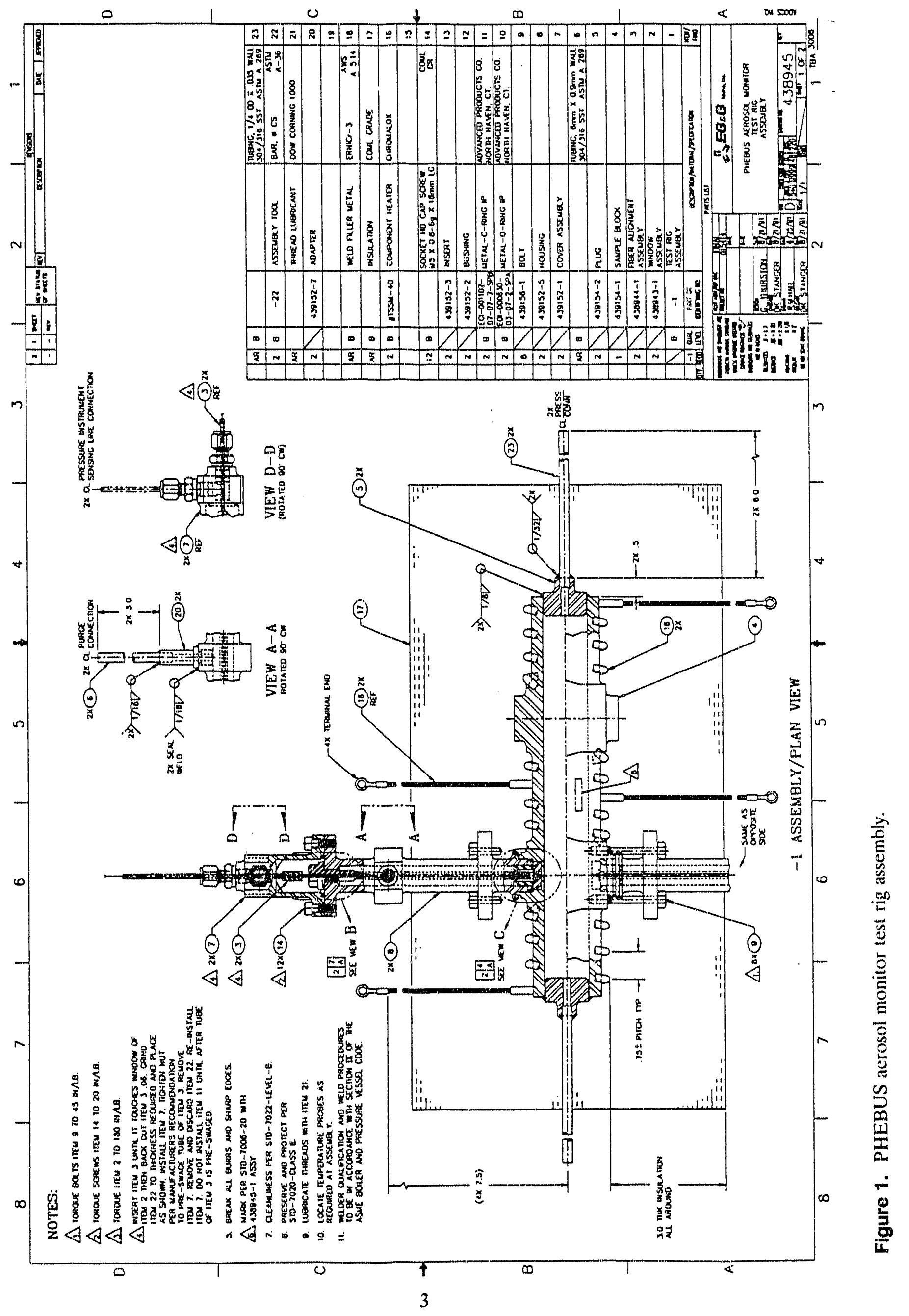




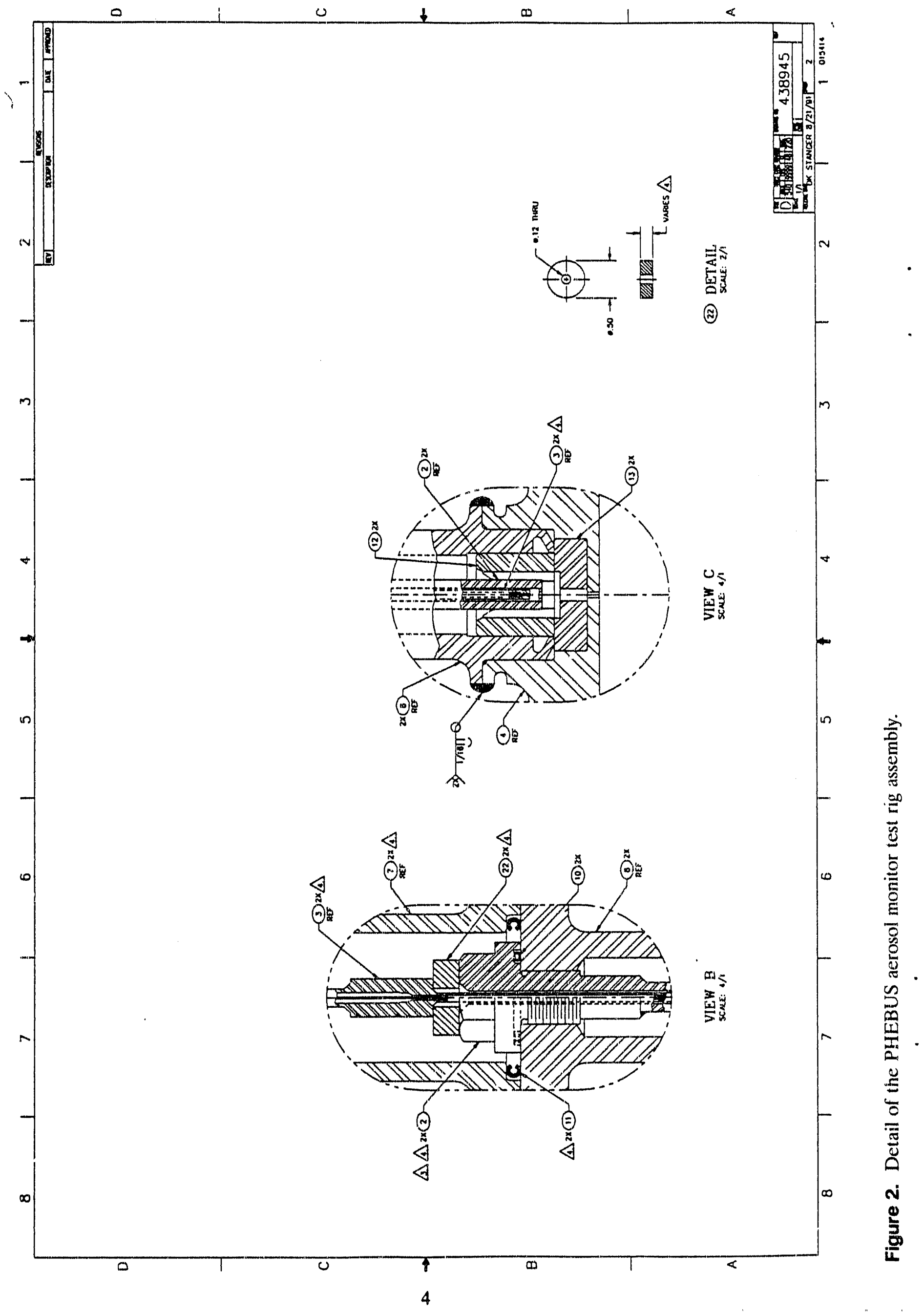




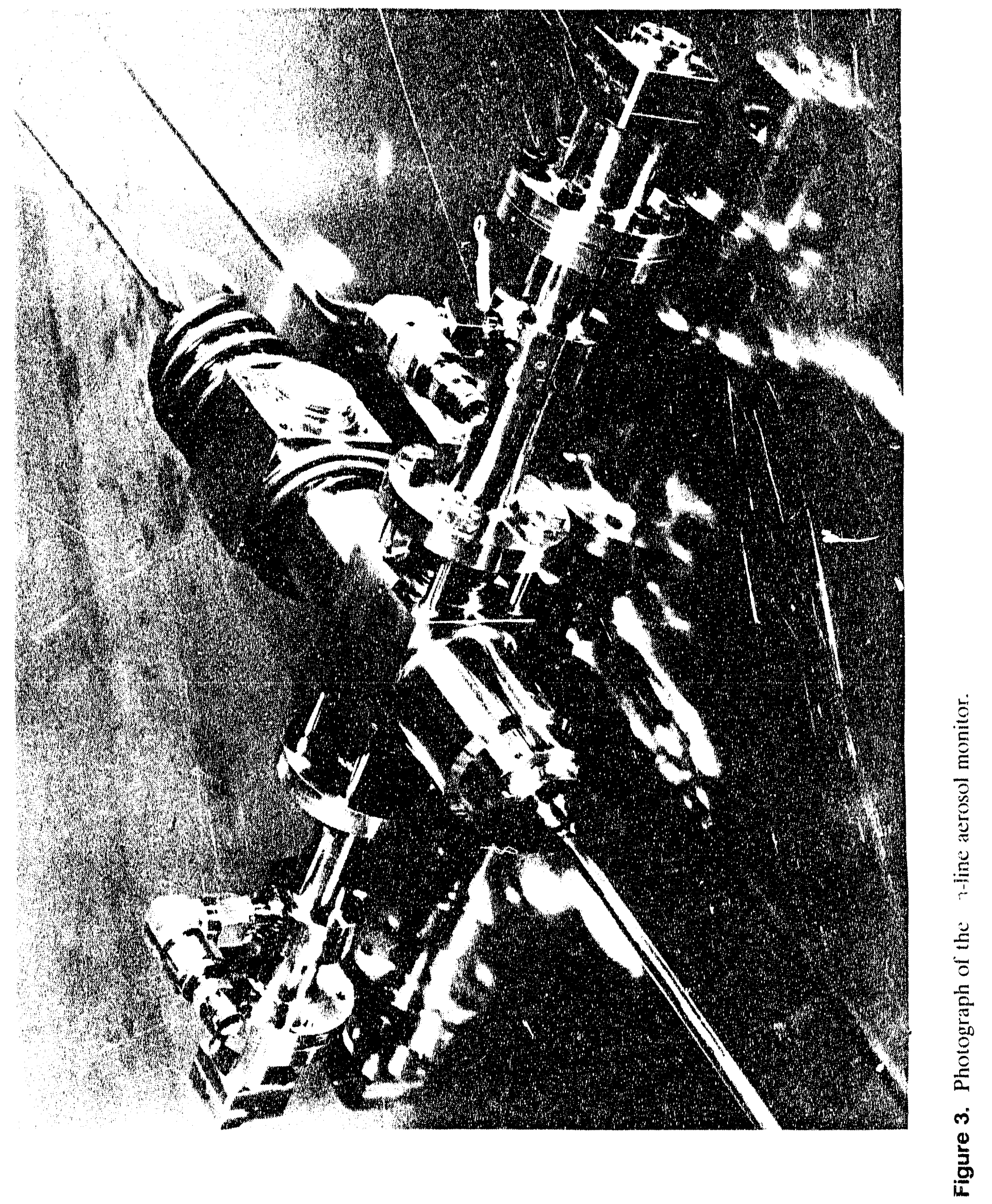




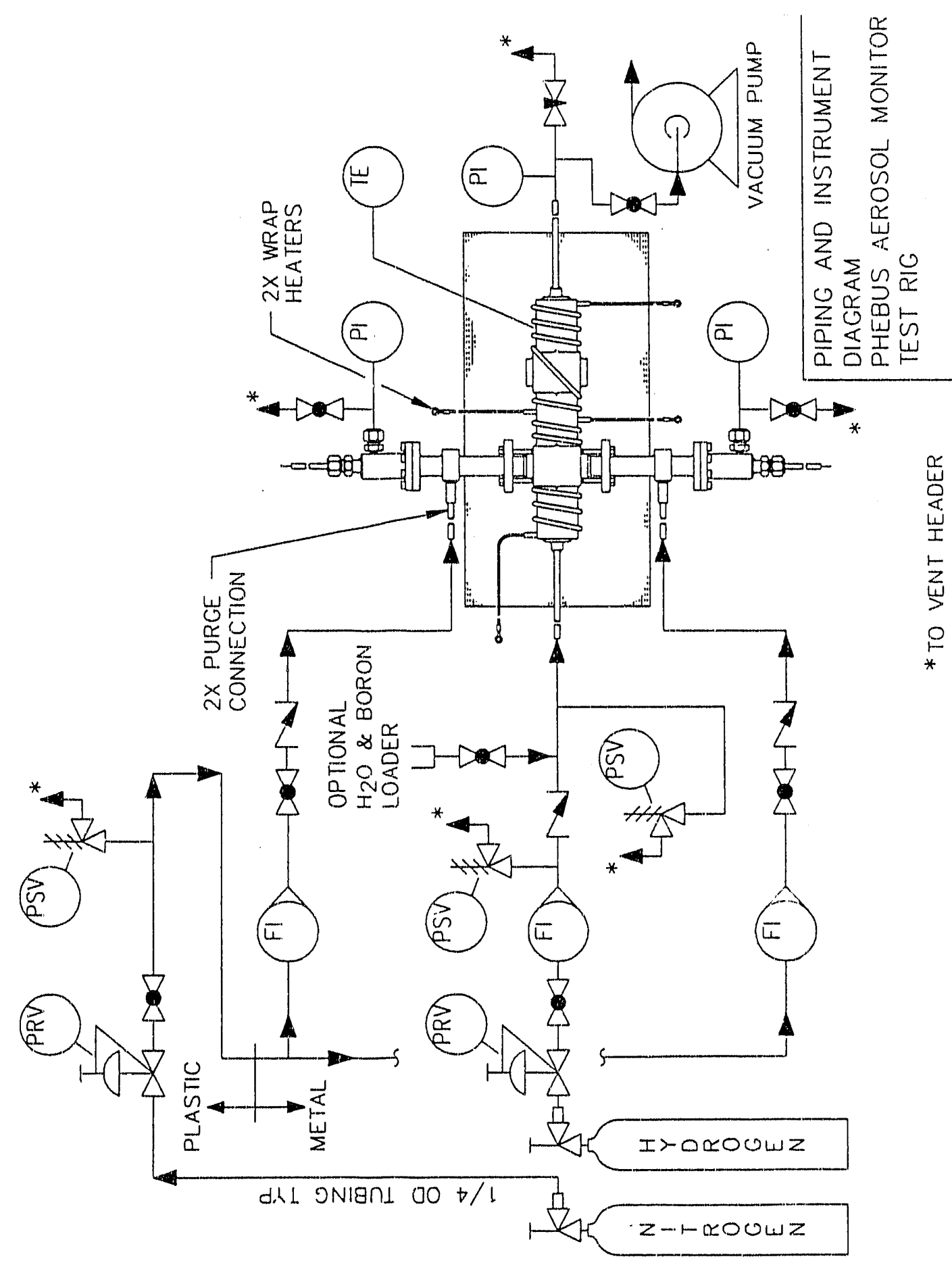

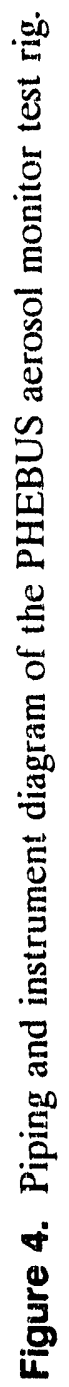




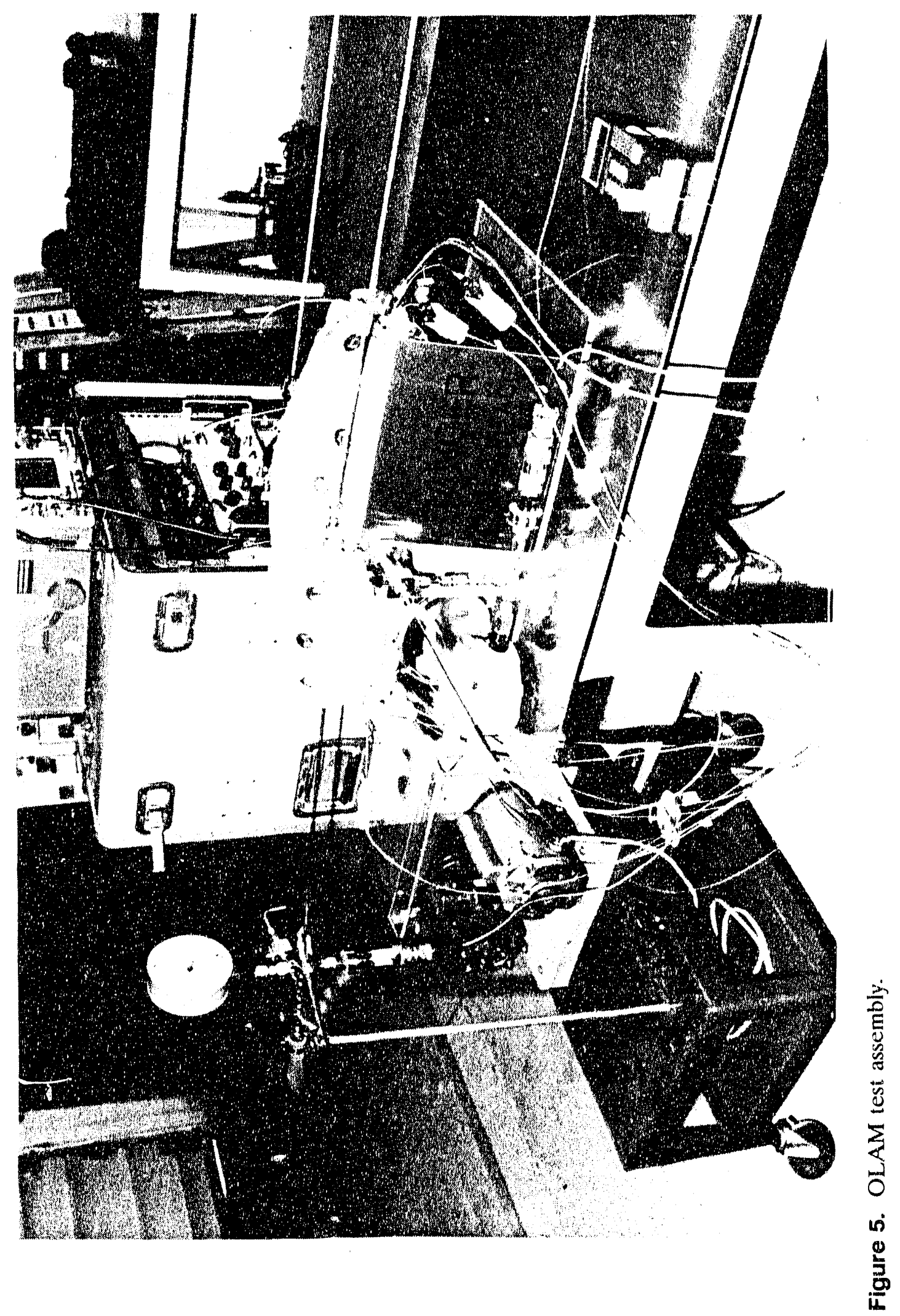




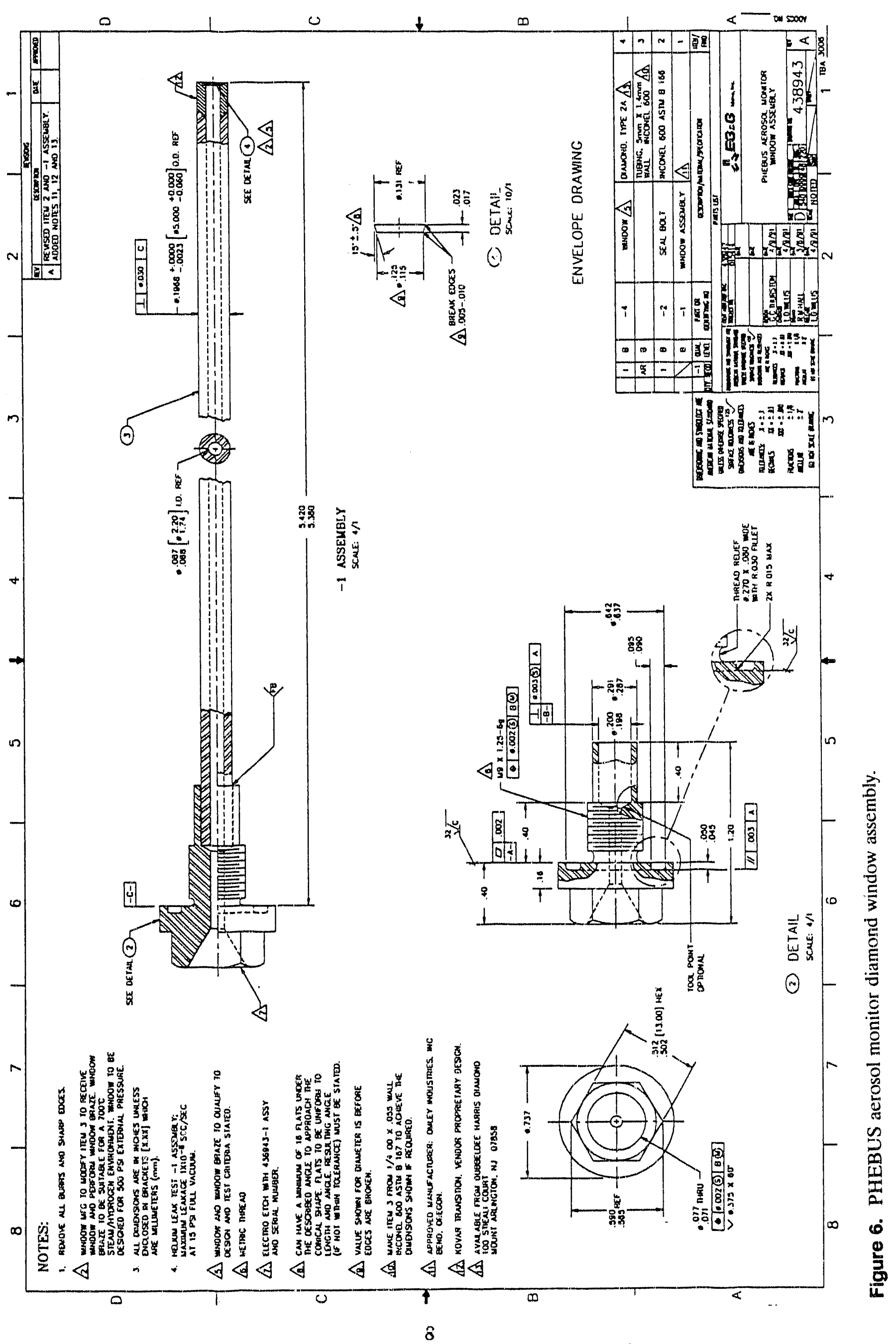




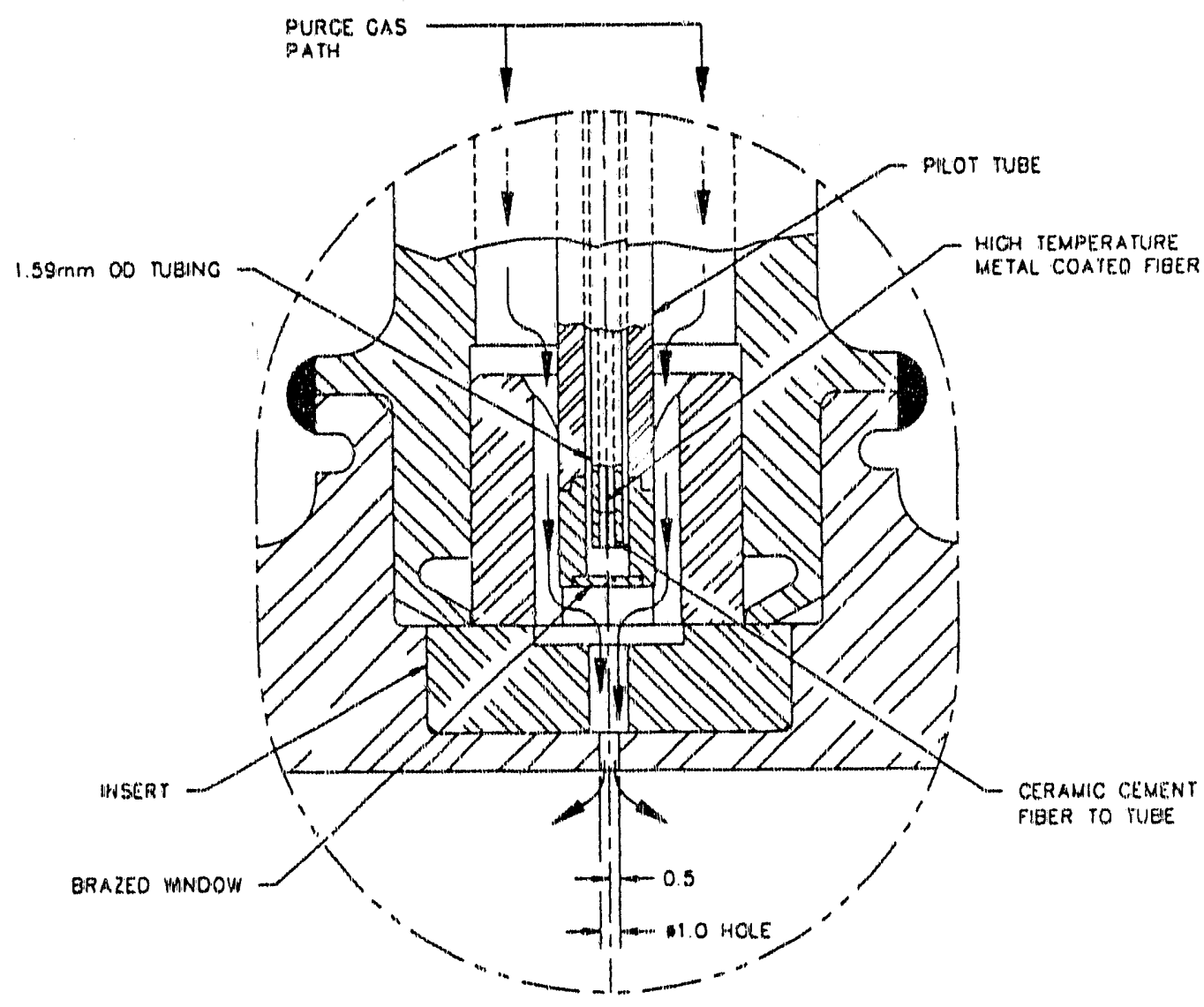

VIEW B

SCALE: $\$ 1$

DRAWING NO. 438946 SHT 2

Figure 7. Diamond window purge assembly. 


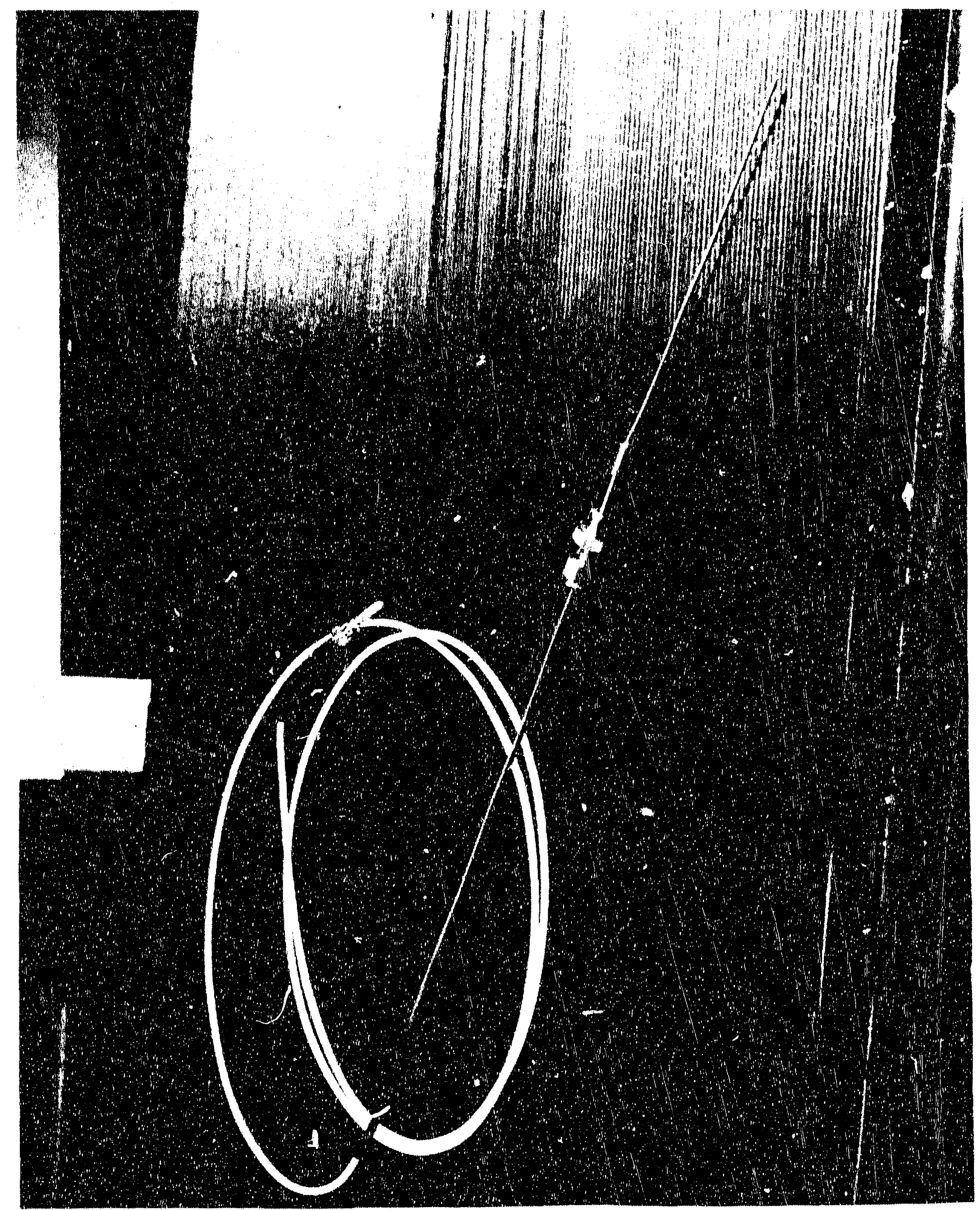

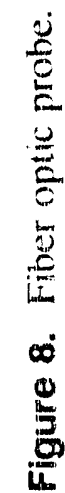




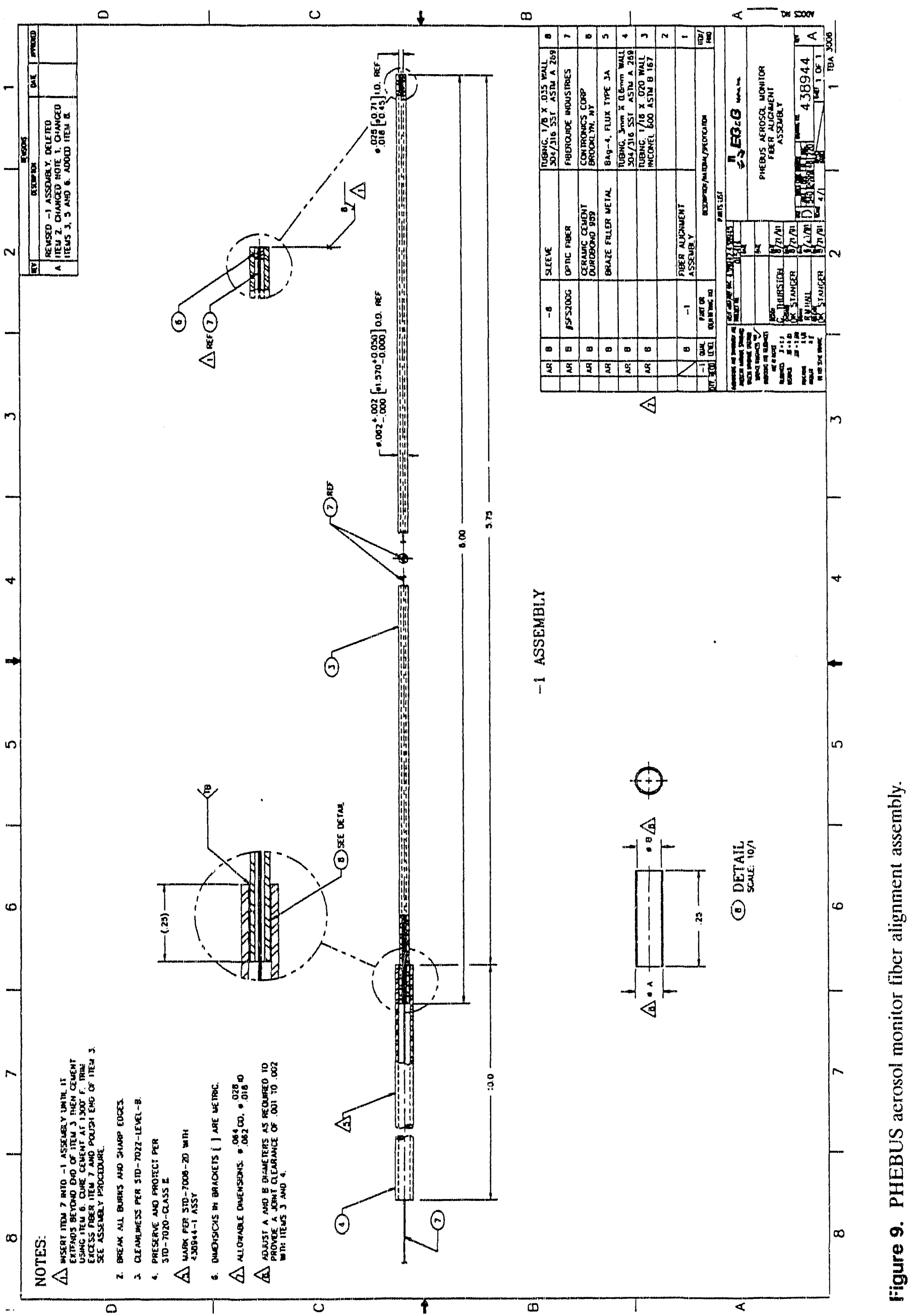




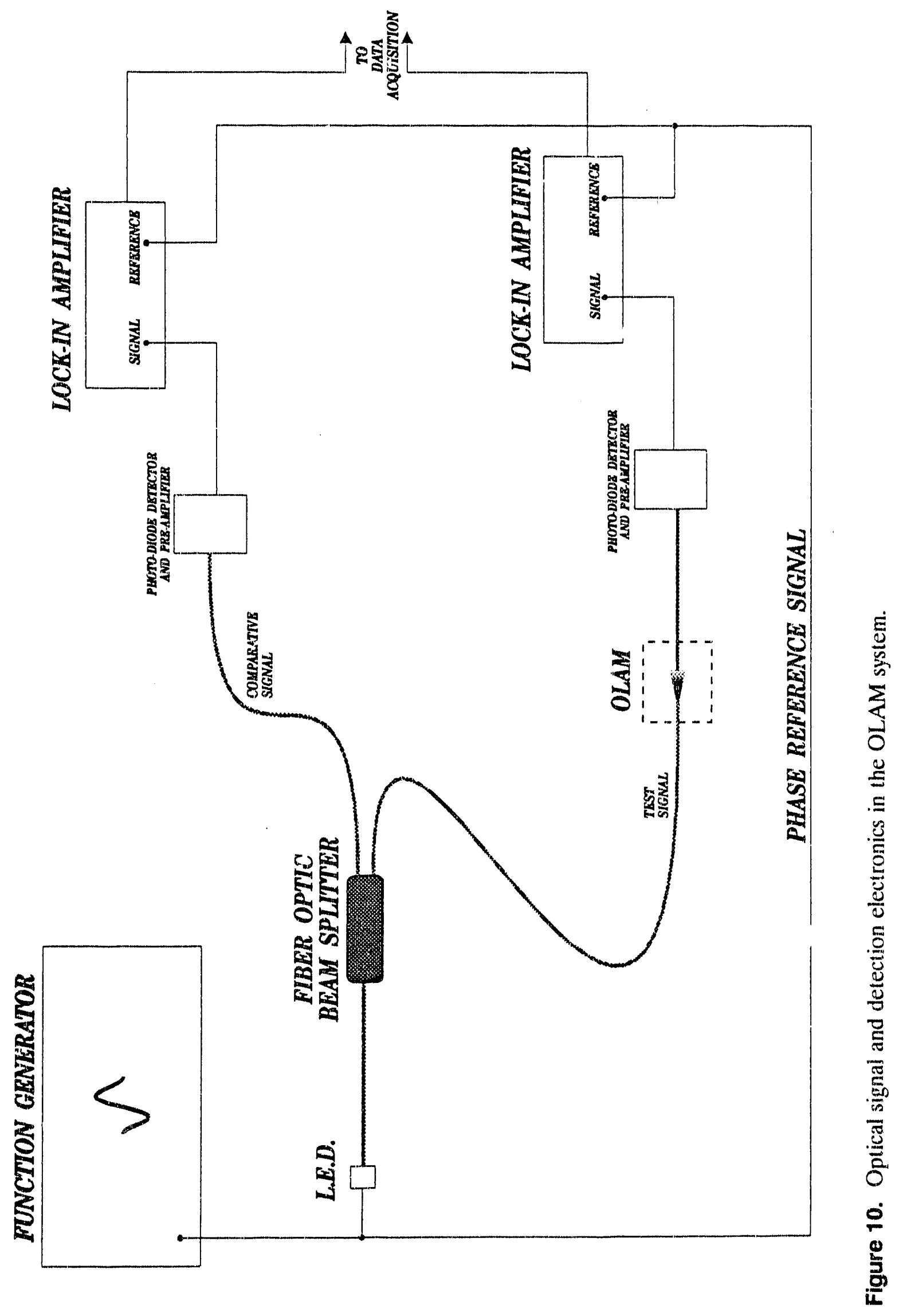




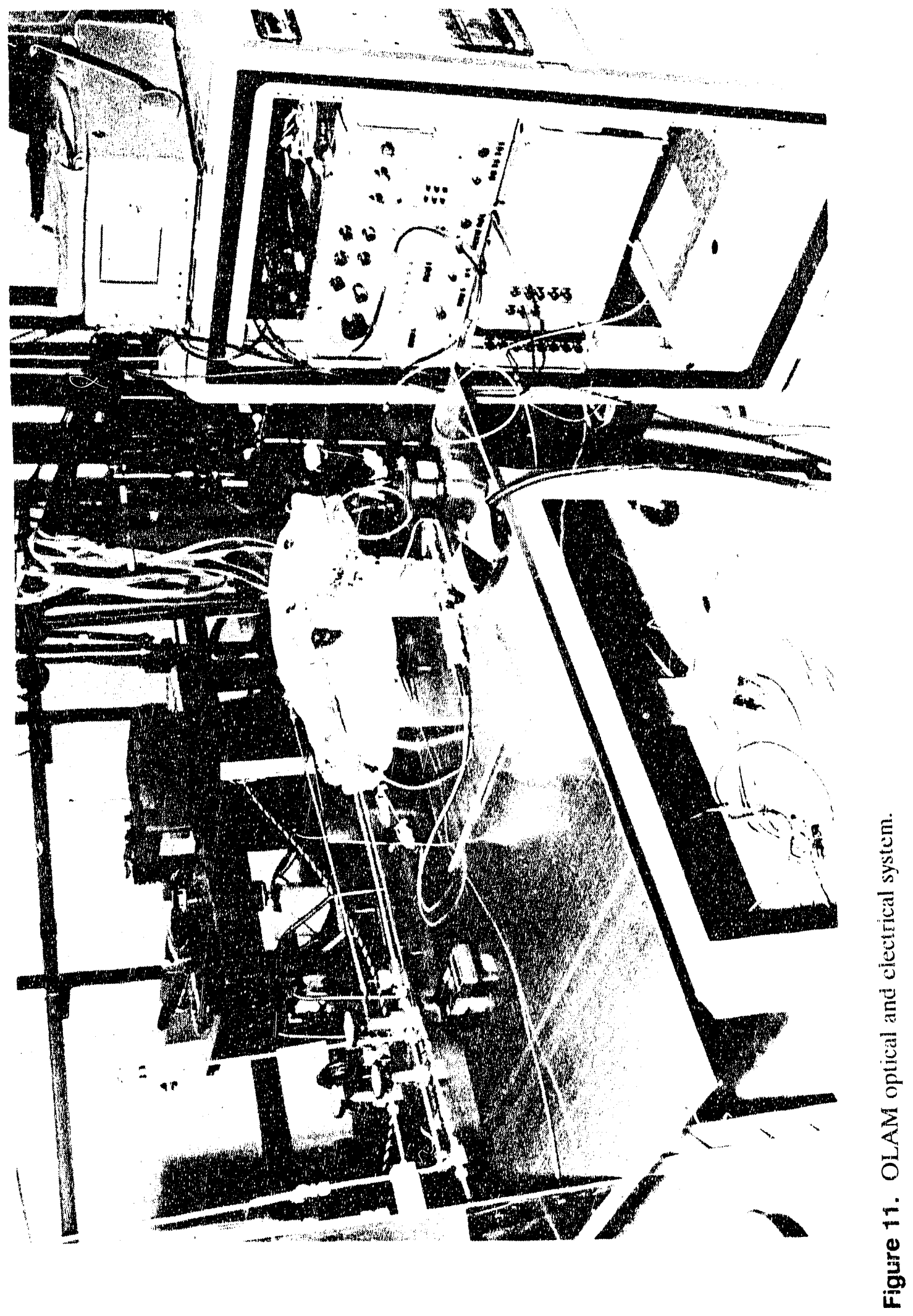




\subsection{Data Acquisition System}

A PC-based, digital 128-channel data acquisition system was used to monitor the temperatures, pressures, optical output, and elapsed time during the testing procedures. The system sampled the output at an approximate rate of five times per second. 


\section{TEST DESCRIPTION}

\subsection{Test Summary}

A series of 20 different tests was conducted during the testing sequence at the NHLF (see Table 1). The tests were designed to verify the mechanical and optical integrity of the OLAM.

The testing process exposed the OLAM to temperatures from $24^{\circ} \mathrm{C}$ to $704^{\circ} \mathrm{C}\left(75^{\circ} \mathrm{F}\right.$ to $\left.1300^{\circ} \mathrm{F}\right)$, at an average ramp of $371^{\circ} \mathrm{C}\left(700^{\circ} \mathrm{F}\right)$ per hour, and pressures of $0.18 \mathrm{MPa}$ to $3.4 \mathrm{MPa}$ (26 psi to $500 \mathrm{psi}$ ). A typical temperature ramp is shown in Figure 12. An environment of nitrogen, steam, or hydrogen was used during the pressurization and testing process. The OLAM was then maintained at the final pressures and temperatures for a given time frame and monitored for pressure, temperature, clapsed time, and optical signal strength. No aerosols were used in this test sequence because the objective was to demonstrate mechanical integrity and optical signal stability.

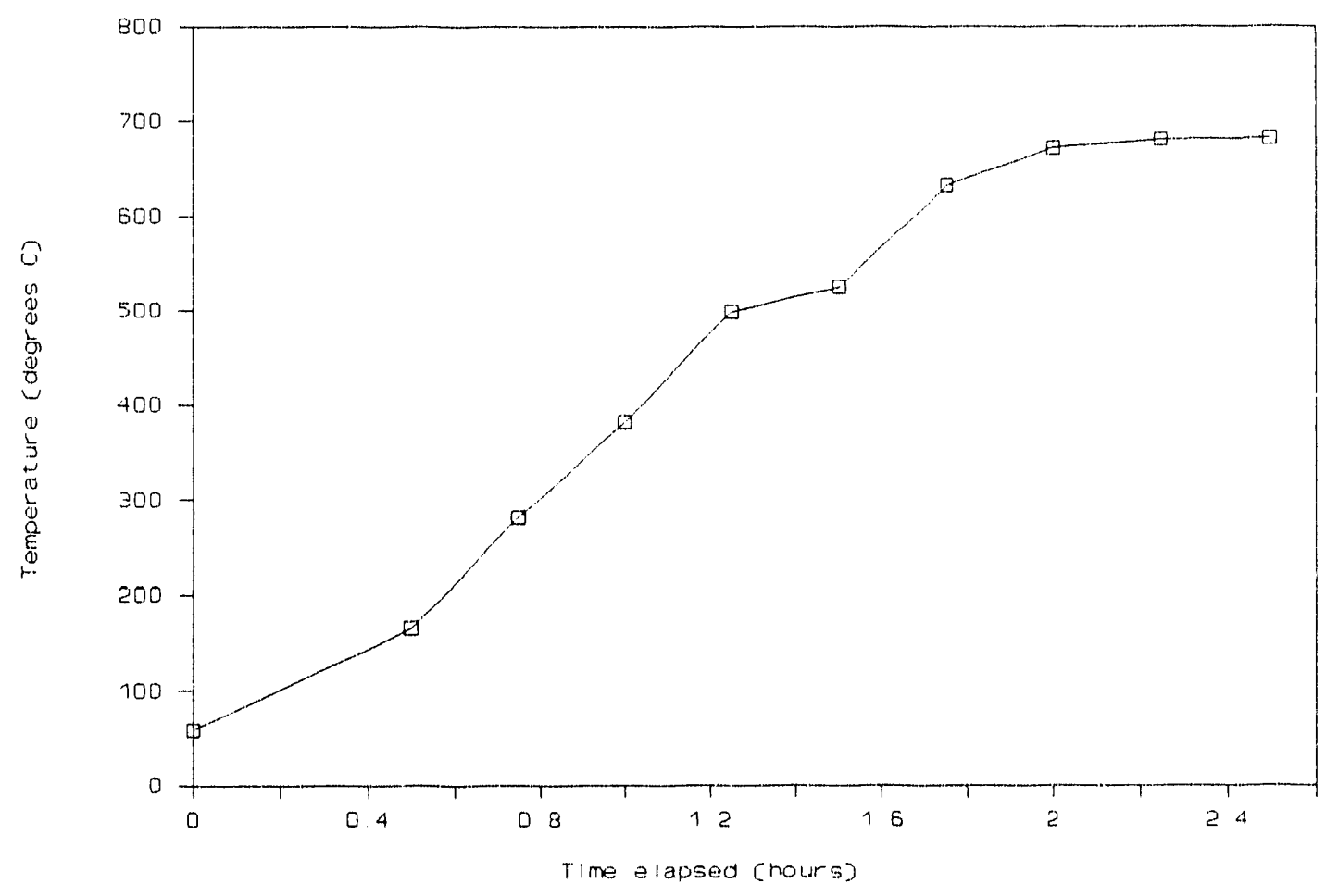

Figure 12. Representative temperature ramp used in NHLF test sequence. 
Table 1. Comprehensive list of tests performed with OLAM.

\begin{tabular}{|c|c|c|c|c|c|c|c|c|c|}
\hline $\begin{array}{c}\text { Test } \\
\text { rumber }\end{array}$ & Begin & End & Hours & $\begin{array}{l}\text { Hours at } \\
\text { temperature }\end{array}$ & $\begin{array}{c}\text { Primary } \\
\text { chamber } \\
\text { gas }\end{array}$ & Pressure & $\begin{array}{c}\text { Optic } \\
\text { probe } \\
\text { set }\end{array}$ & $\begin{array}{l}\text { Secondary } \\
\text { chamber } \\
\text { gas }\end{array}$ & $\begin{array}{l}\text { Opt. } \\
\text { change } \\
\text { per } \\
\text { hour }\end{array}$ \\
\hline 1 & $12 / 18$ & $12 / 18$ & 8.00 & 4.00 & Nitrogen & $1.4 \mathrm{MPa}$ & $\# 1$ & Air & $-3.67 \%$ \\
\hline 2 & $12 / 19$ & $12 / 19$ & 5.00 & 1.75 & Nitrogen & $\begin{array}{l}0.20 \mathrm{MPa} \\
\text { PRG }\end{array}$ & $\# 1$ & Air & $-1.80 \%$ \\
\hline 3 & $i 2 / 20$ & $12 / 20$ & 3.94 & 1.94 & Steam & $0.22 \mathrm{MPa}$ & $\# 1$ & Air & $-0.59 \%$ \\
\hline 4 & $12 / 23$ & $12 / 24$ & 24.00 & 23.50 & Nitrogen & $1.4 \mathrm{MPa}$ & $\# 1$ & Air & $-1.57 \%$ \\
\hline 5 & $12 / 30$ & $12 / 31$ & 25.50 & 23.00 & Nitrogen & $1.4 \mathrm{MPa}$ & $\# 1$ & Air & $\begin{array}{l}+0.22 \\
\%\end{array}$ \\
\hline 6 & $1 / 3$ & $1 / 3$ & 1.60 & 0.00 & Nitrogen & $1.4 \mathrm{MPa}$ & $\# 1$ & Air & $\mathrm{N} / \mathrm{A}$ \\
\hline 7 & $1 / 6$ & $1 / 7$ & 27.50 & 23.50 & Nitrogen & $1.4 \mathrm{MPa}$ & $\# 1$ & Air & $-1.41 \%$ \\
\hline 8 & $1 / 8$ & $1 / 10$ & 46.50 & 43.60 & Nitrogen & $1.4 \mathrm{MPa}$ & $\# 1$ & Air & $-1.03 \%$ \\
\hline 9 & $1 / 15$ & $1 / 16$ & 17.00 & 17.00 & Nitrogen & $1.4 \mathrm{MPa}$ & $\# 2$ & Nitrogen & $-0.13 \%$ \\
\hline 10 & $1 / 16$ & $1 / 17$ & 16.50 & 14.00 & Nitrogen & $1.4 \mathrm{MPa}$ & $\# 2$ & Nitrogen & $\begin{array}{l}+0.21 \\
\%\end{array}$ \\
\hline 11 & $1 / 17$ & $1 / 18$ & 19.00 & 16.50 & Nitrogen & $1.4 \mathrm{MPa}$ & $\# 2$ & Nitrogen & $-0.04 \%$ \\
\hline 12 & $1 / 20$ & $1 / 20$ & 4.50 & 1.75 & Nitrogen & 1.4 $\mathrm{MPa}$ & $\# 2$ & Nitrogen & $\begin{array}{l}+0.28 \\
\%\end{array}$ \\
\hline 13 & $1 / 20$ & $1 / 20$ & 4.70 & 3.50 & Nitrogen & $1.4 \mathrm{MPa}$ & $\# 2$ & Nitrogen & $\begin{array}{l}+0.31 \\
\%\end{array}$ \\
\hline 14 & $1 / 21$ & $1 / 21$ & 3.25 & 0.50 & Nitrogen & $1.4 \mathrm{MPa}$ & $\# 2$ & Nitrogen & $-0.12 \%$ \\
\hline 15 & $1 / 21$ & $1 / 21$ & 2.25 & 1.15 & Nitrogen & $1.4 \mathrm{MPa}$ & $\# 2$ & Nitrogen & $-1.17 \%$ \\
\hline 16 & $1 / 21$ & $1 / 21$ & 4.50 & 3.40 & Nitrogen & $1.4 \mathrm{MPa}$ & $\# 2$ & Nitrogen & $-0.11 \%$ \\
\hline 17 & $1 / 22$ & $1 / 22$ & 8.00 & 5.25 & Nitrogen & $1.4 \mathrm{MPa}$ & $\# 2$ & Air & $-0.95 \%$ \\
\hline 18 & $1 / 22$ & $1 / 22$ & 5.00 & 4.25 & Nitrogen & $1.4 \mathrm{MPa}$ & $\# 2$ & Air & $-1.03 \%$ \\
\hline 19 & $1 / 27$ & $1 / 27$ & 4.00 & 1.50 & $\begin{array}{l}\mathrm{H} 2+ \\
\text { steam }\end{array}$ & $0.18 \mathrm{MPa}$ & $\# 2$ & Nitrogen & $-2.11 \%$ \\
\hline 20 & $1 / 28$ & $1 / 28$ & 1.35 & 0.00 & Nitrogen & $3.4 \mathrm{MPa}$ & $\# 2$ & Nitrogen & N/A \\
\hline
\end{tabular}

Total test hours $=232.1$

Hours at temperatures greater than $782^{\circ} \mathrm{C}=194.3$

During the testing sequence, the mechanical and optical systems proved to be of very high integrity. Since no leaks were detected, the primary and secondary chambers demonstrated that they could provide pressure boundaries at required test conditions. The optical and electrical system also proved its integrity by exceeding the design requirement of less than $10 \%$ optical signal drift during an actual two-hour test sequence. 


\subsection{Initial Test Phase}

During the initial phase of testing, the OLAM was subjected to six different tests for a total of 133 hours of testing. Table 2 lists the tests performed in this phase of testing.

Table 2. Initial phase tests.

\begin{tabular}{ccccccccc}
\hline $\begin{array}{c}\text { Test } \\
\text { number }\end{array}$ & Begin & End & Hours & $\begin{array}{c}\text { Hours at } \\
\text { temperature }\end{array}$ & $\begin{array}{c}\text { Primary } \\
\text { chamber } \\
\text { gas }\end{array}$ & Pressure & $\begin{array}{c}\text { Optic } \\
\text { probe set }\end{array}$ & $\begin{array}{c}\text { Secondary } \\
\text { chamber } \\
\text { gas }\end{array}$ \\
\hline 1 & $12 / 18$ & $12 / 18$ & 8.00 & 4.00 & Nitrogen & $1.4 \mathrm{MPa}$ & $\# 1$ & Air \\
4 & $12 / 23$ & $12 / 24$ & 24.00 & 23.50 & Nitrogen & $1.4 \mathrm{MPa}$ & $\# 1$ & Air \\
5 & $12 / 30$ & $12 / 31$ & 25.50 & 23.00 & Nitrogen & $1.4 \mathrm{MPa}$ & $\# 1$ & Air \\
6 & $1 / 3$ & $1 / 3$ & 1.60 & 0.00 & Nitrogen & $1.4 \mathrm{MPa}$ & $\# 1$ & Air \\
7 & $1 / 6$ & $1 / 7$ & 27.50 & 23.50 & Nitrogen & $1.4 \mathrm{MPa}$ & $\# 1$ & Air \\
8 & $1 / 8$ & $1 / 10$ & 46.50 & 4.3 .60 & Nitrogen & $1.4 \mathrm{MPa}$ & $\# 1$ & Air \\
\hline
\end{tabular}

The initial phase test cycles hegan by loading the OLAM with nitrogen to a static pressure of $0.69 \mathrm{MPa}(100 \mathrm{psi})$. The optical signal was turned on, and the OLAM was heated from room temperature up to $704^{\circ} \mathrm{C}\left(1300^{\circ} \mathrm{F}\right)$, causing the pressure to increase to $1.4 \mathrm{MPa}$ (200 psi). Each subsequent test consisted of holding the OLAM at $704^{\circ} \mathrm{C}\left(1300^{\circ} \mathrm{F}\right)$ for varying lengths of time (see Table 2). For the initial phase of testing, the OLAM was assembled using the first set of windows and fiber optic probes.

Because this test series was intentionally repetitious, some important trends and results were revealed. First, the primary and secondary pressure chambers demonstrated that they could provide pressure boundaries at required test conditions. With one exception, the pressures in the primary and secondary chambers were very stable over the course of the tests. During Test \#6, a mechanical braze developed a minimal leak. The testing was continued using a spare part while the defective one was returned to the manufacturer for tepair.

Second, the optical system also proved that it could meet the accuracy specification stated in the Design Requirements Document" of less than 10\% optical signal drift over the course of an actual 2-hour test. The signal proved to stabilize as the operating temperature was approached. However, a drift in the optical signal was noticed once the OLAM had been at the operating temperature for approximately 20 minutes. Figure 13 illustrates the characteristic signal drift measured. Over this series of tests, the typical decline averaged $1.5 \%$ per hour of the original signal present once the maximum temperature had been reached. This rate of signal drift did not

a. Unpublished report of G. C. Thurston and J. K. Partin, EG\&G Idaho, Inc., Idaho Falls, Idaho, April 1990. 
cause the accuracy of the OLAM to fall below the design requirements, but it appeared to be a factor that could be eliminated by further testing and by implementing modifications.

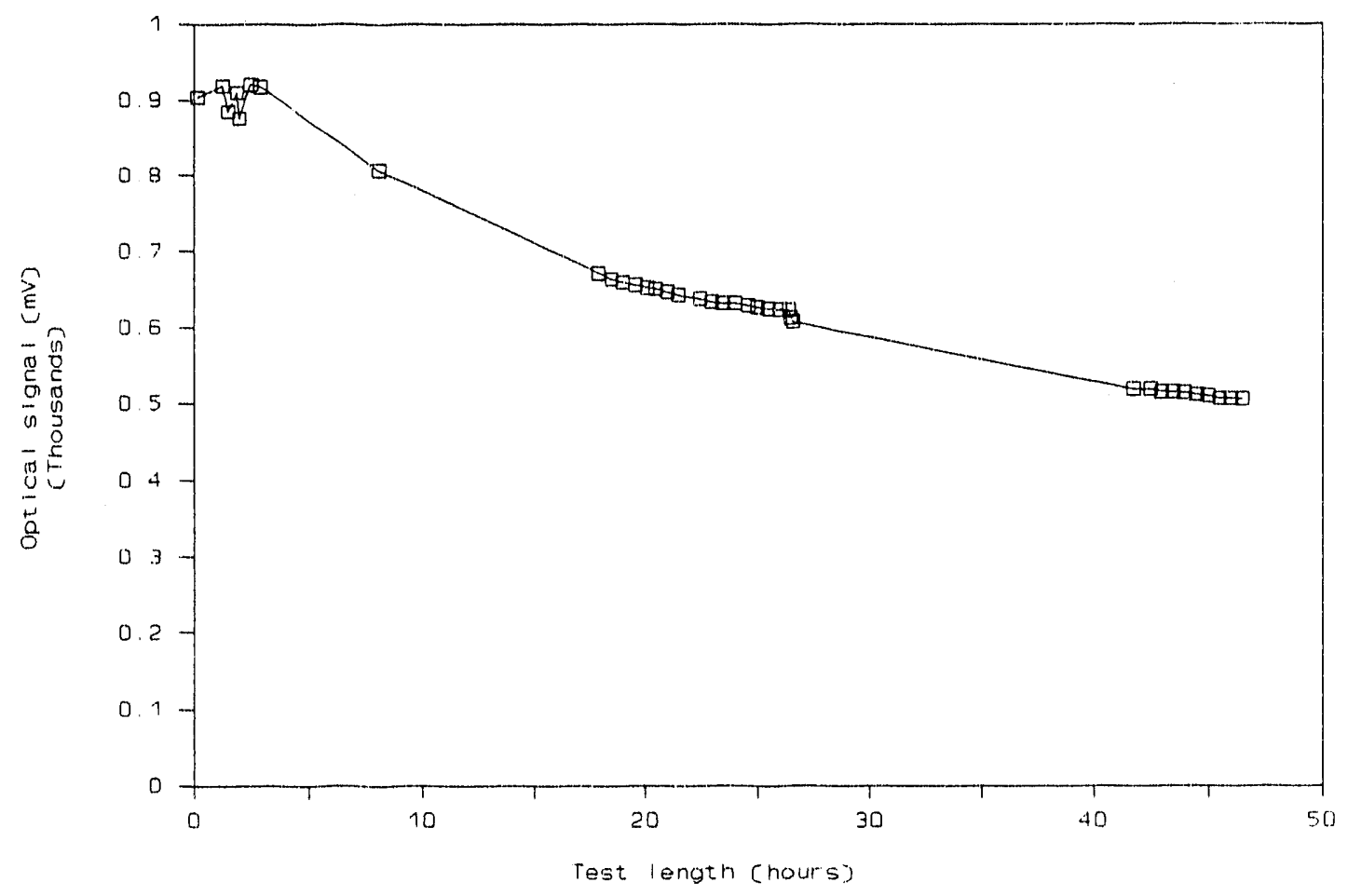

Figure 13. Characteristic signal decrease found during initial test phase.

To further investigate the drifting, the fiber optic probes and window assemblies were removed for inspection at the conclusion of the initial test series. A beam profile analysis displayed that the fibers could still transmit adequate levels of light. However, the fiber probes did display some physical degradation as a result of the testing cycles. One of the probe tips appeared to be partially coated with a granular, oxidized material. Both fiber surfaces were rough and irregular, and one of the surfaces also was cloudy. The ceramic adhesive also showed signs of slight bulging, indicating that the adhesive had not stabilized entirely during the original curing process. (The fiber optic probes had been potted and cured using the adhesive manufacturer's suggested processes.)

The diamond windows were coated with a thin, cloudy film, but on the primary chamber side of the diamond windows, the actual deposits were limited. In contrast, the secondary chamber side showed more deposits and cloudiness. These effects led to the belief that the oxygen environment inside the secondary chamber caused the degradation of the fiber probes and windows, which resulted in the signal drift. 


\subsection{Second Test Phase}

As a result of the observations made after the initial test phase, modifications were implemented during the second phase of testing to eliminate the causes of the signal drift. First, when constructing the second set of fiber optic probes, the adhesive was cured according to the manufacturer's instructions, followed by an extended post-cure $(17$ hours $)$ at $704^{\circ} \mathrm{C}\left(1300^{\circ} \mathrm{F}\right)$. The adaitional post-cure stabilized the adhesive at high temperatures and reduced the possibility of off-gassing. Before installation back into the window assemblies, the new probes were also cleaned thoroughly to eliminate any effects caused by contaminants. Finally, the secondary chambers surrounding the probes were backfilled with nitrogen at a slightly positive pressure of $0.03 \mathrm{MPa}(5 \mathrm{psi})$. Replacing the air with nitrogen served two purposes: no oxidation could occur if the oxygen had been eliminated, and no residual moisture would be present to potentially attack the silica fiber. Otherwise, conditions were identical to those during the initial test series.

The second test phase consisted of ten different test cycles: eight using the new nitrogen back-fill, followed by two allowing air back into the secondary chamber. Table 3 lists the tests performed in the second phase of testing. The tests lasted for a total of 84.5 hours, and had an average length of 8.5 hours at the maximum temperature range. During the second phase of testing, the OLAM was again loaded with nitrogen and heated to $704^{\circ} \mathrm{C}\left(1300^{\circ} \mathrm{C}\right)$.

Table 3. Second phase tests incorporating system modifications.

\begin{tabular}{ccccccccc}
\hline $\begin{array}{c}\text { Test } \\
\text { number }\end{array}$ & Begin & End & Hours & $\begin{array}{c}\text { Hours at } \\
\text { Temperature }\end{array}$ & $\begin{array}{c}\text { Primary } \\
\text { chamber } \\
\text { gas }\end{array}$ & Pressure & $\begin{array}{c}\text { Optic } \\
\text { probe } \\
\text { sct }\end{array}$ & $\begin{array}{c}\text { Sccondary } \\
\text { chamber } \\
\text { gas }\end{array}$ \\
\hline 9 & $1 / 15$ & $1 / 16$ & 17.00 & 17.00 & Nitrogen & $1.4 \mathrm{MPa}$ & $\# 2$ & Nitrogen \\
10 & $1 / 16$ & $1 / 17$ & 16.50 & 14.00 & Nitrogen & $1.4 \mathrm{MPa}$ & $\# 2$ & Nitrogen \\
11 & $1 / 17$ & $1 / 18$ & 19.00 & 16.50 & Nitrogen & $1.4 \mathrm{MPa}$ & $\# 2$ & Nitrogen \\
12 & $1 / 20$ & $1 / 20$ & 4.50 & 1.75 & Nitrogen & $1.4 \mathrm{MPa}$ & $\# 2$ & Nitrogen \\
13 & $1 / 20$ & $1 / 20$ & 4.70 & 3.50 & Nitrogen & $1.4 \mathrm{MPa}$ & $\# 2$ & Nitrogen \\
14 & $1 / 21$ & $1 / 21$ & 3.25 & 0.50 & Nitrogen & $1.4 \mathrm{MPa}$ & $\# 2$ & Nitrogen \\
15 & $1 / 21$ & $1 / 21$ & 2.25 & 1.15 & Nitrogen & $1.4 \mathrm{MPa}$ & $\# 2$ & Nitrogen \\
16 & $1 / 21$ & $1 / 21$ & 4.50 & 3.40 & Nitrogen & $1.4 \mathrm{MPa}$ & $\# 2$ & Nitrogen \\
17 & $1 / 22$ & $1 / 22$ & 8.00 & 5.25 & Nitrogen & $1.4 \mathrm{MPa}$ & $\# 2$ & Air \\
18 & $1 / 22$ & $1 / 22$ & 5.00 & 4.25 & Nitrogen & $1.4 \mathrm{MPa}$ & $\# 2$ & Air \\
\hline
\end{tabular}

Changes in the optical signal performance were immediately evident. Once the OLAM had stabilized at the operating temperature and pressure, the signal remained very steady with minimal drift or decline. Figure 14 illustrates the stability of the optical signal shown in Test \#11. During the second phase of testing, the signal remained within $1.5 \%$ of its initial value. 


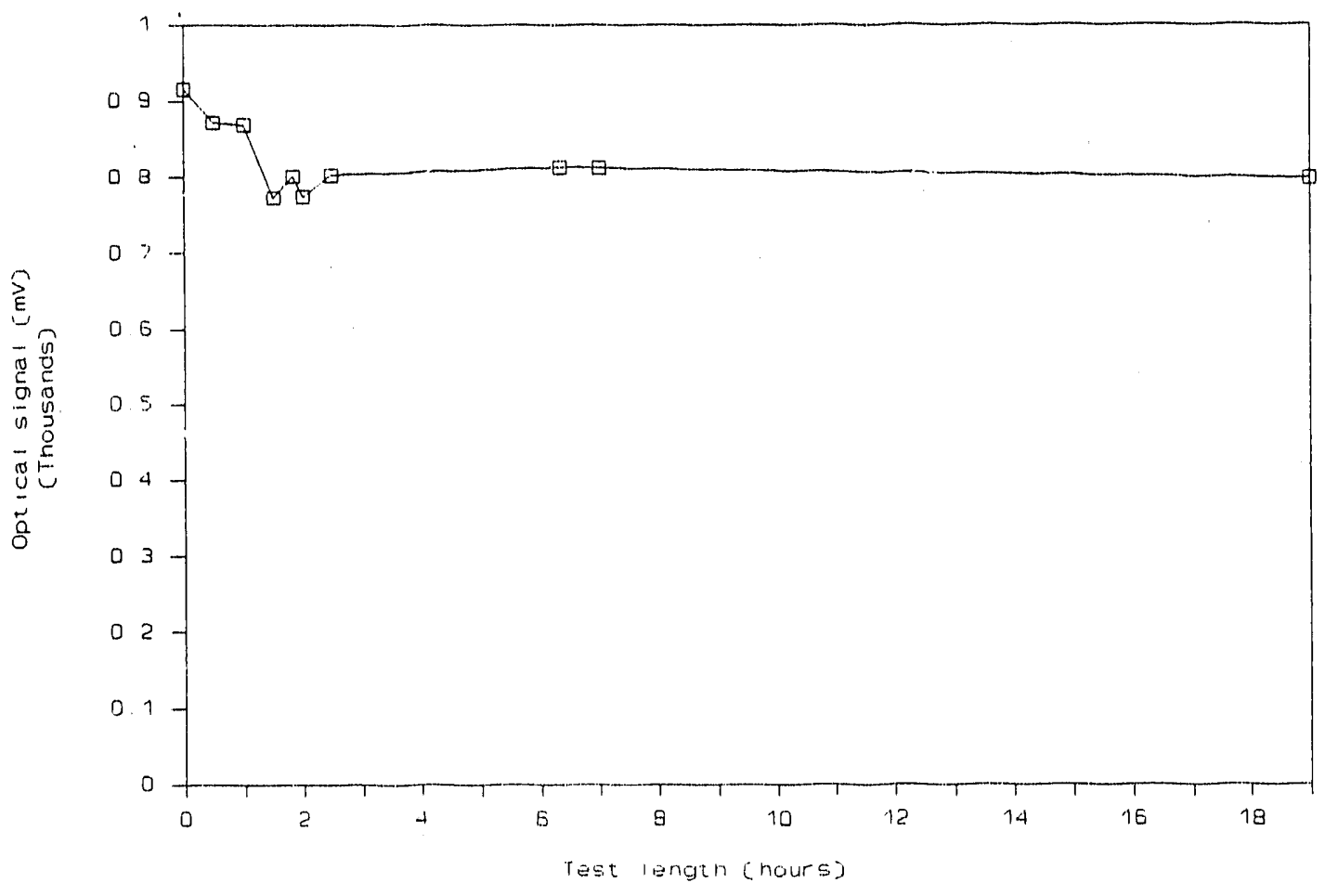

Figure 14. Stable optical signal demonstrated after system modifications.

Periodic physical inspection of the optic probes, during the second test phase, revealed major differences in the impact on the fibers. With the use of the nitrogen backfill, no oxidation was present, and the fiber faces showed only very minor variations. The ceramic adhesive also showed no change in appearance. When examined with a beam analysis program, the light transmission through the probes was still of good quality.

The final portion of the second phase testing consisted of allowing air back into the secondary chambers while running two more thermal cycles (Tests \#17 and \#18). The change back to air was made to determine if the nitrogen backfill was really the reason that the optical signal had stabilized. During these test cycles, the optical signal returned to the original pattern of steady decline as in the initial testing series. In each case, once the OLAM had reached operating temperature and pressure, the optical signal began to decline at rates between $1.0 \%$ and $1.7 \%$ per hour. Inspection of the optic probes after the two tests also showed accelerated degradation. Each probe now exhibited a discolored deposit on the metal and adhesive surfaces. Both fibers were recessed, and one of the fiber surfaces was markedly rougher than when last inspected, with a noticeable decline in beam transmission quality. 


\subsection{Specialty Tests}

To complete the testing, several single purpose tests were conducted during the initial and secondary test phases. These tests used a variety of primary chamber test fluids, including the following: nitrogen with a nitrogen purge (Test \#2), steam and nitrogen (Test \#3), a mixture of hydrogen and steam (Test \#19), and nitrogen at $3.4 \mathrm{MPa}(500 \mathrm{psi}$ ) (Test \#20). Table 4 lists the specialty tests performed.

Table 4. Special purpose tests performed during the initial and second phases.

\begin{tabular}{ccccccccc}
\hline $\begin{array}{c}\text { Test } \\
\text { number }\end{array}$ & Begin & End & Hours & $\begin{array}{c}\text { Hours at } \\
\text { temperature }\end{array}$ & $\begin{array}{c}\text { Primary } \\
\text { chamber gas }\end{array}$ & Pressure & $\begin{array}{c}\text { Optic } \\
\text { probe } \\
\text { set }\end{array}$ & $\begin{array}{c}\text { Secondary } \\
\text { chamber } \\
\text { gas }\end{array}$ \\
\hline 2 & $12 / 19$ & $12 / 19$ & 5.00 & 1.75 & Nitrogen & $0.20 \mathrm{MPa}, \mathrm{PRG}$ & $\# 1$ & Air \\
3 & $12 / 20$ & $12 / 20$ & 3.94 & 1.94 & Steam $+\mathrm{N}_{2}$ & $0.22 \mathrm{MPa}$ & \#1 & Air \\
19 & $1 / 27$ & $1 / 27$ & 4.00 & 1.50 & $\mathrm{H} 2+$ steam & $0.18 \mathrm{MPa}$ & \#2 & Nitrogen \\
20 & $1 / 28$ & $1 / 28$ & 1.35 & 0.01 & Nitrogen & $3.4 \mathrm{MPa}$ & \#2 & Nitrogen \\
\hline
\end{tabular}

Tests \#2 and \#3 used the first optic probe set, and the secondary chamber was filled with air. For Test \#2, the OLAM was operated with a constant purge flow of nitrogen at a rate of 30 $\mathrm{cm}^{3} / \mathrm{min}$ and a pressure of $0.21 \mathrm{MPa}$ (30 psi). Mechanically and optically, the OLAM purge performed as designed. However, because this testing was done earlier in the testing program, the optical signal displayed the same decline that was characteristic of the other initial phase tests.

Test \#3 entailed loading the OLAM with steam instead of nitrogen. Deionized water was drawn into the main spool piece by applying a vacuum. The water vaporized as the OLAM temperature increased, inducing a linal pressure of $0.22 \mathrm{MPa}(32 \mathrm{psi})$. After the OLAM reached operating temperature and pressure, the optical output stabilized, but again started to show the same characteristic initial test phase decline. The OLAM functioned as expected with the steam environment and no impact was found on the OLAM assemblies.

Tests \#19 and \#20 were conducted using the second set of optic probes, and the secondary chamber was backfilled with nitrogen. During Test \#19, hydrogen and deionized water were loaded into the OLAM at room temperature. The hydrogen and steam mixture was used to simulate the constituents of the actual test flow and to thoroughly leak test the OLAM system. Following the loading, the OLAM was brought up to temperature and to a final pressure of $0.18 \mathrm{MPa}(26 \mathrm{psi})$. The optical signal was very stable once the operating temperature had been reached and displayed no drifting. The primary and secondary chambers again proved to provide a tight pressure boundary at test conditions. 
The final test, Test \#20, was designed to test the mechanical integrity of the OLAM at much higher pressures. The OLAM was taken to $3.4 \mathrm{MPa}(500 \mathrm{psi})$ at $704^{\circ} \mathrm{C}\left(1300^{\circ} \mathrm{F}\right)$. The optical signal remained strong and steady throughout the test, but was not of primary importance. Instead, the ability of the OLAM to remain leak-free at elevated pressures was observed. As Figure 15 shows, the pressure was stable at the maximum temperature and pressure.

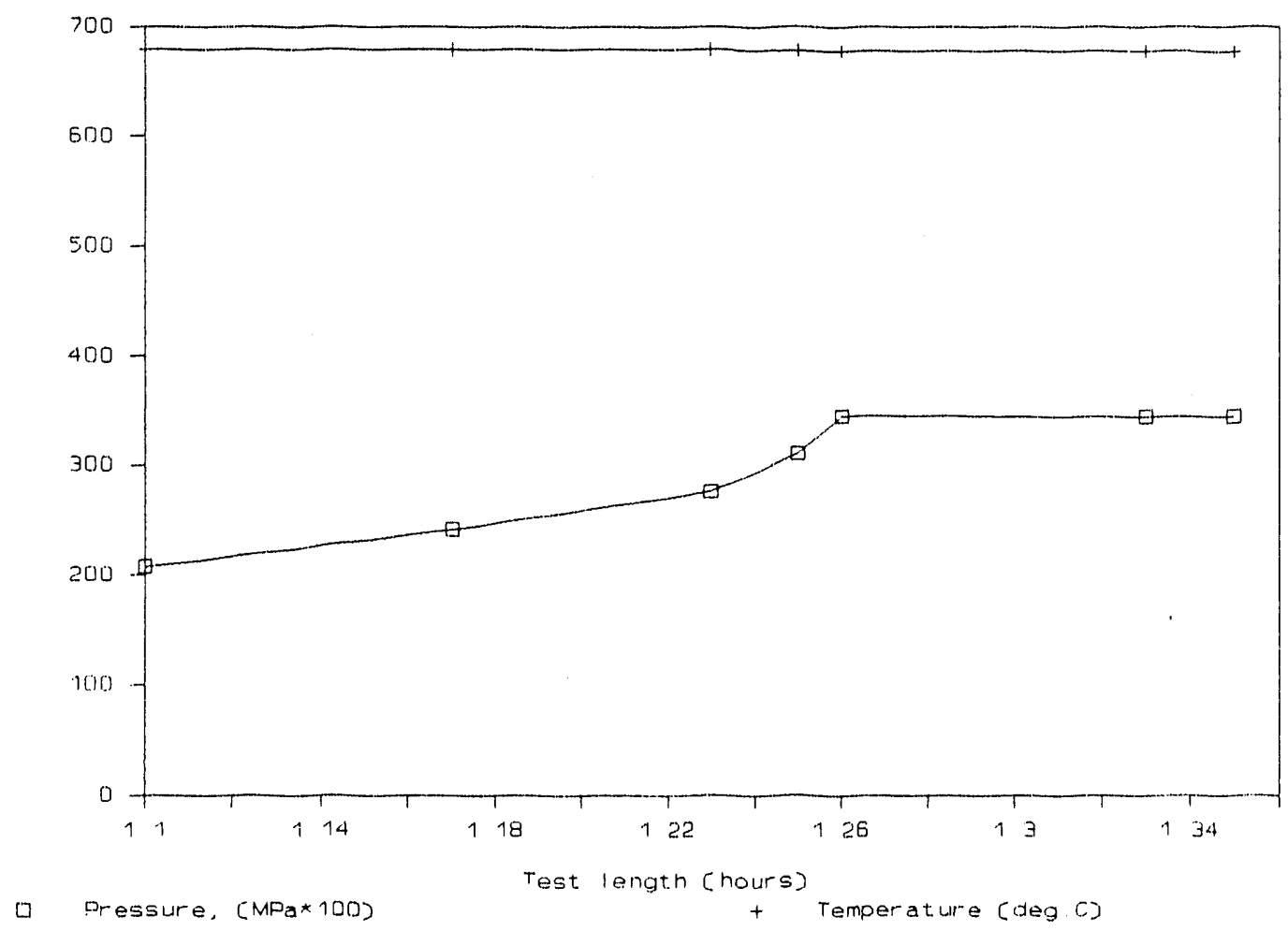

Figure 15. Mechanical integrity of the OLAM at high pressures and temperatures. 


\section{CONCLUSIONS}

The following conclusions were drawn from the OLAM testing:

- The OLAM will function properly over pressure and temperature ranges of $0 \mathrm{MPa}$ to $3.4 \mathrm{MPa}$ ( $(9 \mathrm{psi}$ to $500 \mathrm{psi})$ and $16^{\circ} \mathrm{C}$ to $704^{\circ} \mathrm{C}(60)^{\circ} \mathrm{F}$ to $\left.1300^{\circ} \mathrm{F}\right)$ using environments of nitrogen, hydrogen, and steam.

- The optical and electronic system met the Design Requirements Document specification of less than $10 \%$ optical signal drift during an actual two-hour test sequence.

- The process of curing the fibers at high temperatures and backfilling the secondary chambers with nitrogen is needed to prevent signal drift. This process will be performed with the production unit.

- Test \#2 demonstrated that the purge system did not affect the optical signal performance. 


\section{Appendix A \\ Test Plan for OLAM Testing}

December 1991 


\title{
Appendix A \\ Test Plan for OLAM Testing
}

\author{
INTRODUCTION
}

This test plan defines the details of engineering-scale testing to be performed on the PHEBUS Fission Product Project (PHEBUS-FP) on-line aerosol monitor (OLAM). The testing will take place at the Idaho National Engineering Laboratory's North Hoimes Lab Facility (NHLF). The main objectives of the testing are to determine the mechanical integrity of the aerosol monitor and to conduct preliminary testing of the optical system.

\section{PROJECT DESCRIPTION}

The aerosol monitor designed for this project is based on a sucuessful instrument pteviously developed by EG\&G Idaho for use in the Power Burst Facility to study aerosols generated during severe core damage events. Aerosols are detected by passing a light beam through a gas stream and measuring the change in intensity caused by the presence of particles. The change in light intensity is a function of the particle concentration, particle size, and path length. The major components of the monitor are a light source, light detector, signal electronics, and the mechanical parts required to implement the task. The light is transmitted from the viewing ports across the flow stream to the receiving ports through fiber optics.

To allow the study of severe accident conditions in a controlled manner, the PHEBUS project simulates the reactor core, primary circuit, and containment building of a full-size pressurized waicr reactor. A driver core is used to control a one-meter long test bundle containing approximatcly 20 fucl rods. The fission product release is expected to be about one five thousandth that of a full sizc core. The primary coolant flow is from the test bundle up through a heated section of line into a horizontal line to a steam generator, cold leg, and containment tank; all this equipment will be placed in a containment structure (caisson). The aerosol monitor will be located in the horizontal line that runs from the heated section to the steam generator within the caisson. The electronics associated with the aerosol monitor will be located outside the caisson.

The goal of the PHEBUS-FP Project is to obtain experimental information about the chemical and physical properties of fission products and aerosols released under severe reactor accident conditions. 


\section{OBJECTIVES}

The objectives of this test are two-fold. Step one is to ensure the mechanical integrity of the monitor assembly at operating temperature and pressure, and step two is to perform a preliminary test on the design of the optical system.

\section{TEST SPECIMEN CONFIGURATION}

The test monitor includes a straight pipe spool section with a single port for sending a light beam through the flowing fluid, a light sensor for receiving and sending the light to a remote location, and signal electronics for detecting and recording at the remote location. The test monitor's configuration is the same as the final deliverable product's configuration, except that a single optic port will be used in the testing procedure (see Figure 1).

The test rig system includes the test monitor and a pressurized nitrogen and hydrogen system to enable the flow and purge system to be used in the testing (see Figure 2). A wrap heater system will also be included in the test rig system to enable the monitor to be heated to different temperatures. Various tubing, fittings, valves, gauges, and insulation will be included to complete the test rig system. A stand will be built to mount the test rig.

\section{TEST LIMITS AND PRECAUTIONS}

The following test limits and precautions shall apply to the testing.

- Construction proof test-A proof test will be performed to ensure the quality and safety of the work performed by the manufacturer. Since the test is performed at room temperature, the pressure will be increased to give an equivalent stress level in the test rig. The potential risk also necessitates that the test be performed remotely.

- $\quad$ )esign pressure $=500 \mathrm{psig}(3.4 \mathrm{MPa})$ maximum

- $\quad$ Proof test pressure $=330$ psig $(2.3 \mathrm{MPa})$ maximum

- Design temperature $=1300^{\circ} \mathrm{F}\left(704^{\circ} \mathrm{C}\right)$

- Hot gas-The test rig will contain pressurized gas as hot as $1300^{\circ} \mathrm{F}\left(704^{\circ} \mathrm{C}\right)$. The design must therefore prevent personnel and equipment damage from this source. As a result, check valves will be placed in the purge lines to prevent back flow. 
- Relief valves-Pressure relief valves will be installed to protect the test rig against over pressurization.

- Oxygen evacuation-The system will not be heated until all oxygen has been evacuated from the test rig.

- Hydrogen gas usage-To ensure safe use of the hydrogen gas, the job safety analysis will be followed, small hydrogen supply bottles will be used, and a safety manifold vented to the outside of the building will be installed.

\section{TEST SEQUENCE}

The testing will be performed in the following sequence (after the proof test is completed).

\section{Test 1-Cold Leak Test}

Test 1 is a cold leak test in which the specimen will first be pressurized to 350 psig (2.4 MPa) using nitrogen and then examined for leaks using a solution of soap and water. During the cold leak test, the specimen will not be heated, insulated, or have the purge flow connected.

\section{Test 2-Hot Leak and Operational Test}

Test 2 is a static pressure test with nitrogen gas. The specimen will be evacuated and pressurized to $100 \mathrm{psig}(0.69 \mathrm{MPa})$ using the nitrogen gas. A pretest of the optical system will be performed following the pressurization to check the alignment, the sending and receiving units, and the electronic system. Following pretest checkout of the optical system, the specimen will be insulated and heated to $1300^{\circ} \mathrm{F}\left(704^{\circ} \mathrm{C}\right)$. After reaching $1300^{\circ} \mathrm{F}\left(704^{\circ} \mathrm{C}\right)$, the systern pressure will reach approximately $200 \mathrm{psig}(1.4 \mathrm{MPa})$. During the testing process, the data acquisition system will monitor the specimen's temperature, pressure (both system and secondary chamber pressure), and optical output. If, after establishing steady state conditions in any test scenario, the optical output drops by $25 \%$ of its initial value, an ofi-normal condition exists and the test should be evaluated for causes of the optical drop. The temperature ramping should not exceed $700^{\circ} \mathrm{F} /$ hour $\left(371^{\circ} \mathrm{C} /\right.$ hour $)$.

\section{Test 3-Leak and Operational Test With Purge Flow}

Test 3 is a dynamic test with a purge flow connected. The specimen will again be pressurized, heated, and examined in the same manner as in Test 2. The new testing step, the purge flow, will aid 
in further detcrmination of the mechanical integrity and optical precision of the system. The purge flow of nitrogen will be approximately $30 \mathrm{~cm}^{3} / \mathrm{min}$.

\section{Test 4-Leak and Operational Test With Steam}

Test 4 is a static pressure test with a steam environment. The specimen will first be heated to $600^{\circ} \mathrm{F}\left(316^{\circ} \mathrm{C}\right)$, and $2.6 \mathrm{~cm}^{3}$ of deionized water will be loaded into the specimen using a water column loader. The specimen will then be ramped to $1300^{\circ} \mathrm{F}\left(704^{\circ} \mathrm{C}\right)$ and inspected for leaks, pressure decay, and optical output under the steam environment. The pressure will increase to 200 psig (1.4 MPa) because of the addition of the water and the increase in temperature.

\section{Test 5-24 Hour Operational Test}

Test 5 is a 24 hour static operational test with nitrogen gas. The specimen will again be pressurized, heated, and examined in the same manner as in Test 2. However during this test, the specimen will be held at $1300^{\circ} \mathrm{F}\left(704^{\circ} \mathrm{C}\right)$ for 24 hours to ensure that the optical signal level does not drop significantly (greater than $25 \%$ loss) during this time span.

\section{Test 6-Thermal Cycles Test}

Test 6 is a static test that will incorporate the same environment as used in Test 2 . This test will subject the specimen to 10 temperature cycles $\left(70^{\circ} \mathrm{F}\right.$ to $\left.1300^{\circ} \mathrm{F}\right)\left(21^{\circ} \mathrm{C}\right.$ to $\left.704^{\circ} \mathrm{C}\right)$ at a ramp of not more than $700^{\circ} \mathrm{F}\left(371^{\circ} \mathrm{C}\right)$ per hour. The optical stability and mechanical integrity will be checked periodically throughout the process.

\section{Test 7-Hydrogen and Steam Test}

Test 7 is also a static test that will use a severe environment consisting of hydrogen and stcam. The specimen will be loaded with hydrogen and water, heated, and monitored for mechanical and optical integrity according to the test procedures stated in Section 8.1. To ensure safe use of the hydrogen gas, the precautions in Section 6 will be followed. 


\section{TEST PROCEDURES}

Test procedures will be developed informally for all tests, except for the hydrogen and steam test, as the testing process continues. The procedures for the Hydrogen and Steam Test are as follows:

- Evacuate the air from the $180 \mathrm{cc}$ lecture cylinder.

- Load the lecture cylinder, using the main hydrogen bottle located in the NHLF bottle rack, to a pressure of $25 \mathrm{psig}(0.17 \mathrm{MPa})$.

- Evacuate the test monitor, then move the grounded cart and test assembly outside to charge the test monitor.

- Attach the lecture cylinder to the test monitor, open the appropriate valves and let the pressures equalize in the test monitor and the lecture cylinder.

- $\quad$ Close the appropriate valves and remove the lecture cylinder. Take the lecture cylinder back outside and vent the hydrogen remaining in the cylinder into the atmosphere. Backflush the cylinder with nitrogen and again vent the eylinder into the atmosphere.

- Bring the cart and test assembly back into the building, and position the cart in the test area so that it is four feet from any electrical fixtures or combustibles. Make surc that the test monitor and cart are properly grounded.

- Load $6 \mathrm{~cm}^{3}$ of deionized water into the vertical loading column. Bleed the nitrogen inlet valve to ensure that all air is displaced from the nitrogen tubing. Open the valve and load the water into the test monitor using a low nitrogen back pressure ( 5 to $10 \mathrm{psig})(0.03$ to $0.07 \mathrm{MPa})$.

- Remove all personnel from the test area. Start the red warning light. Tum on the electronics and start the heat ramp. Allow the test monitor to reach $1300^{\circ} \mathrm{F}\left(704^{\circ} \mathrm{C}\right)$ and hold it. at that temperature range for one hour.

- After the testing process is complete, allow the test monitor to cool to room temperature before venting the hydrogen. Once the monitor has cooled, take the cart back outside and vent the hydrogen in the test monitor to the atmosphere. Purge the test monitor with nitrogen two times to remove any remaining hydrogen and again vent to the outside air with each purge.

\section{Special Precautions:}

- If the test assembly leaks after the heat ramp has been started, one person can enter the test area to locate the problem provided the following conditions are met: 
a. The test monitor temperature is below the autoignition temperature of $1076^{\circ} \mathrm{F}$ $\left(580^{\circ} \mathrm{C}\right)$.

b. The power has been disconnected to the heaters.

The test monitor can be left overnight unattended. However, at the completion of the testing day, do not leave the monitor unattended until the test monitor is below the autoignition temperature of $1076^{\circ} \mathrm{F}\left(580^{\circ} \mathrm{C}\right)$. If the test monitor is left overnight, vent the system and reload with new hydrogen before restarting the testing process the following day.

If problems more serious than leakage occur, evaluate the problem to determine the course of action needed. Before entering the test area, make sure the following conditions are met:

a. The test monitor temperature is below the autoignition temperature of $1076^{\circ} \mathrm{F}$ $\left(580^{\circ} \mathrm{C}\right)$.

b. The power has been disconnected to the heaters.

\section{EQUIPMENT LIST}

\section{Equipment Provided by the PHEBUS-FP Project}

- 3 flow meters $\left(0-100 \mathrm{~cm}^{3} / \mathrm{min}\right.$.).

- 3 pressure relief valves (750 psig or $5.2 \mathrm{MPa}$ maximum) set at $500 \mathrm{psig}(3.4 \mathrm{MPa}$ ).

- 3 metering valves (small orifices)

- 3 block valves (high temperature)

- 3 ball valves

- 3 check valves (high temperature)

- 6 female $1 / 4$ NPT to $1 / 4$ Swagelok connectors

- Miscellaneous fittings and tubing

- $\quad$ High temperature insulation $\left(1300^{\circ} \mathrm{F}\right)\left(704^{\circ} \mathrm{C}\right)$ 


\section{Equipment Provided By NHLF}

- Pressurized nitrogen and hydrogen bottles.

- Small vacuum pump and gauge to evacuate OLAM

- Power supply (110V and 220V)

- Isolated test area with controlled access

- 2 pressure regulators $(0-800 \mathrm{psig})(0-5.5 \mathrm{MPa})$

- Temperature controller $\left(50-1500^{\circ} \mathrm{F}\right)\left(10-816^{\circ} \mathrm{C}\right)$, and interface for heaters

- Thermocouples, central display, and recording device

- Data acquisition system to monitor system temperature, pressure, and optical output

- Miscellaneous fittings and tubing (6- $T$ and 8-90 fittings, $50 \mathrm{ft}$ of $1 / 4$-in. stainless tubing and $20 \mathrm{ft}$. of plastic tubing).

- 5 pressure gauges $(0-600 \mathrm{psi})(0-4.1 \mathrm{MPa})$.

- 3 pressure transducers to monitor system pressure and metal seal leak detection system (secondary chamber).

- Small hand tools to assemble the test unit.

- Support assembly or stand to mount test unit on. To be built by technician as required.

- Blast protection from possible failure.

\section{MEASUREMENT PARAMETERS}

The following measurement parameters will be met.

- Samples of the flow gas used in Test 3 will be taken to ensure the composition of the mixture. 
- The pressure gauges will have an accuracy of $\pm 2 \%$ of the span.

The flow meters will have an accuracy of $\pm 2 \%$.

\section{SAFETY AND OPERATING CONDITIONS}

A safety engineer will review all test sequences to ensure that appropriate company-specificd safety standards and controls are developed and followed. The safety engineer will also verify that action items, as designated by the job safety analysis, are being performed.

\section{QUALITY CONTROL}

Quality control levels will be followed as described in the EG\&G Quality Manual. The quality controlling document from the EG\&G Quality Manual is number QP-11, Section 7.

\section{DOCUMENTATION}

Each test will be assigned a test number and date. Data sheets will be kept from the recording devices for each test. During the experimental process, a logbook will be kept to record data, outputs, and findings. A final report will also be produced summarizing all findings from the testing. 


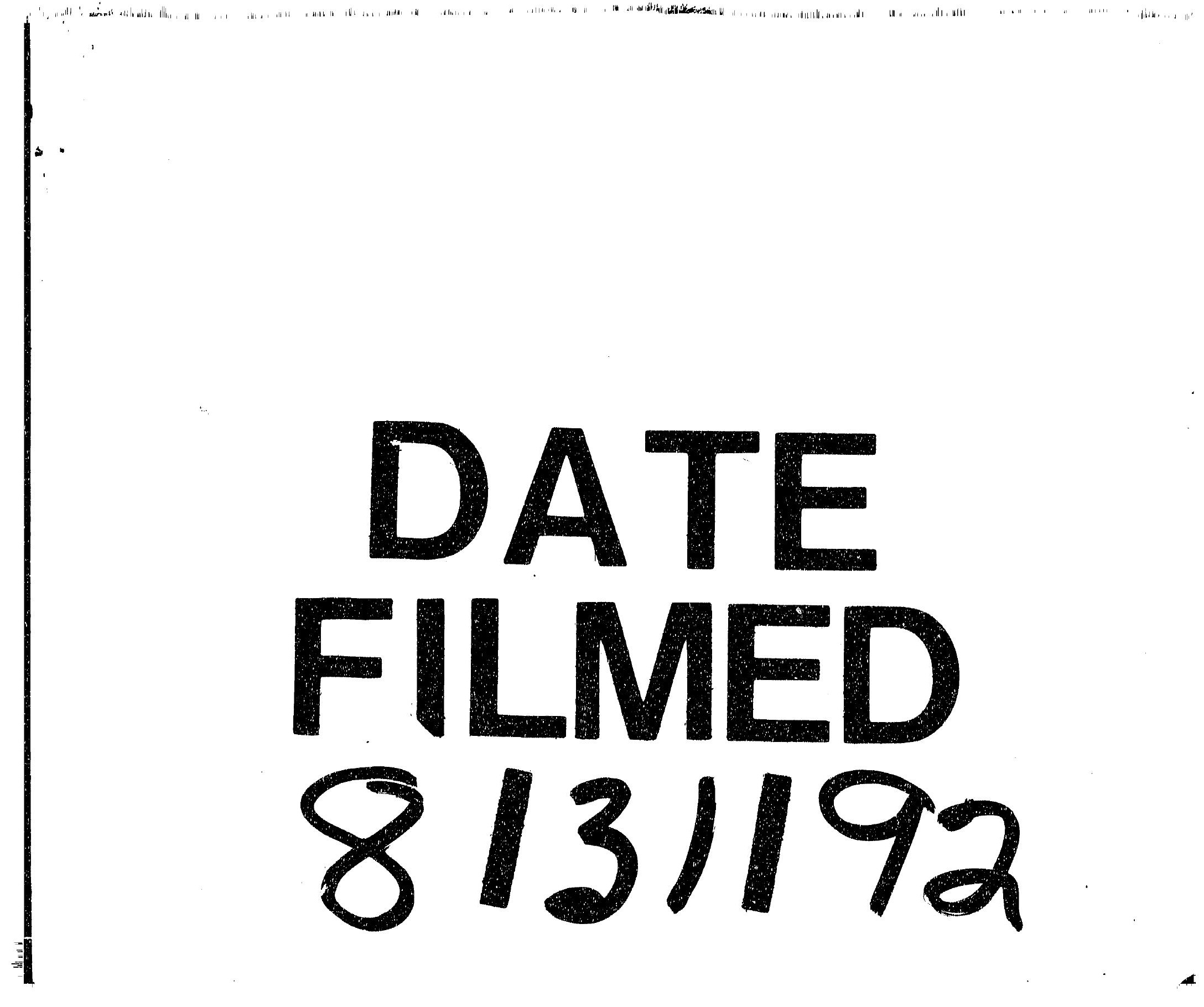




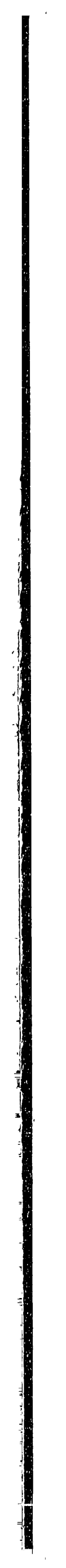

